Portland State University

PDXScholar

\title{
A Comparison of Responses Between Two Different Socioeconomic Groups on the Boehm Test of Basic Concepts
}

Teri Jones Geist

Portland State University

Follow this and additional works at: https://pdxscholar.library.pdx.edu/open_access_etds

Part of the Speech Pathology and Audiology Commons Let us know how access to this document benefits you.

Recommended Citation

Geist, Teri Jones, "A Comparison of Responses Between Two Different Socioeconomic Groups on the Boehm Test of Basic Concepts" (1975). Dissertations and Theses. Paper 2036.

https://doi.org/10.15760/etd.2035

This Thesis is brought to you for free and open access. It has been accepted for inclusion in Dissertations and Theses by an authorized administrator of PDXScholar. Please contact us if we can make this document more accessible: pdxscholar@pdx.edu. 
AN ABSTRACT OF THE THESIS OF Terl Jones Geist for the Master of Science in Speech Commurication: Emphasis in Speech Pathology/Audiology presented February 14, 1975.

Title: A Comparison of Responses Between Two Dsfrerent Socioeconomic Groups on the Boehm Test of Basic Concepts.

APPROVED BY MEMBERS OF THE THESIS COMMTTYEE:

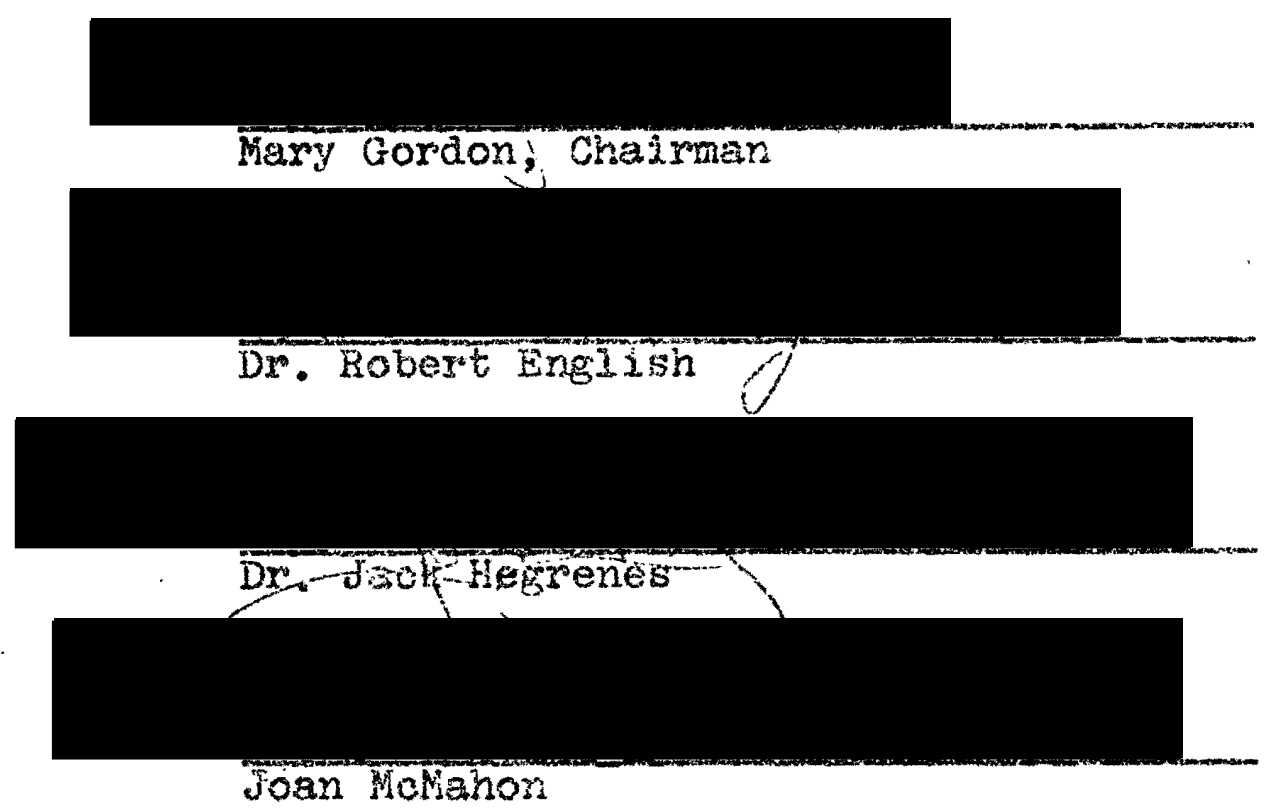

The primary purpose of this investigation was to compare the responses of white, lower-class kindergartners nid pirst graders ath white, middle-class kindergartners and first graders on the Boehn Test of Besic Concepts (BTBC) (Boehm, 1969) in order to determine if a statisticaly signdicint 
difference existed between socioeconomic level and the number of concepts correctly identified on the BTBC. A secondary purpose was to determine if a significant relationship existed between concept development as measured by the BTBC and intelligence from an assessment of receptive vocabulary by using the Peabody Picture Vocabulary Test (PPVT) (Dunn, 1959).

one humared white, lower and midare soctoeconomic level children from two elementary schools in Portland were selected as subjects to be included in this study. Variables controlled were grade level, auditory acuity, emotional stability, and socioeconomic status.

The BTBC consists of fifty pictorial items, arranged in approximate order of difficulty and divided evenly between two booklets. Included in the fifty items are twenty-three spatial concepts, four time concepts, eighteen quantity con cepts, and five concepts classified as miscellaneous. The PPVI was used to provide an estimate of a subject's verbal intelifigence through a measurement of his receptive rocabulary. On both tests, the subject was instructed to point to the pioture representing the stimulus item.

The results of this study revealed a relationship exists between socioeconomic status and the number of concepts correctly identified on the $\mathrm{BTBC}$. This relationship was observed when the lower-class subjects were compared with their midale-class peers at each grade level, when all kindergartoners were compared to all first graders, and in a conpapison of the fifty lower-class and fifty midale-class subjects. 
The subjects of the middle socioeconomic level tended to identify more concepts correctly than the subjects of the lower socioeconomic level, while the first grade subjects, generalIy, identified more concepts correctly than the kindergartners. An analysis of the conceptual areas of space, time, and quantity revealed that socioeconomic status was related to the number of concepes correctly identifled when the If lower-class subjects were compared to the fifty middle-class subjects. The children of the middle-class identified more concepts correctly in each area than the lower-class subjects. Grade level also was related to the number of concepts correctly identified in each of the concept areas. The first graders tended to identify more concepts in each area than the kindergartners. When the scores of the lower-and midaleclass subjects at the kindergarten level were compared, there was no relationship between socioeconomic status and the number of concepts correctly identified in each of the three areas. No relationship was observed between the scores of the two groups of first graders on the spatial concepts. Som cioeconomic level, however, did effect the number of time and quantity concepts correctly identified. The subjects of the middle socioeconomic level, generally, identified more time and quantity concepts correctly than the subjects of the lower soctoeconomic level.

These results suggest a higher degree of abstraction abiIities may be found with increased age and a higher socioeconomic level. The sindings also tend to support the views of 
4

many researchers in the field of conceptual development who have stated that the language of the disadvantaged child inhibits his ability to abstract.

Results of a Pearson's Product-Moment correlation calculated between the subjects' scores on each of the tests indcoated no significant correlation between the children's I.Q. scores and the number or concepts correctly identified. 
A COMPARISON OF RESPONSES BETWEEN TWO DIFFERENT SOCIOECONOMIC GROUPS ON THE BOEHM TEST OF BASTC CONCEPTS

\author{
by \\ TERI JONES GEIST
}

A thesis submitted in partial fulfillment of the
requirements for the degree of

MASTER OF SCIENCE IN SPEECH COMMUNICATION

with an emphasis in

SPEECH PATHOLOGY AND AUDIOLOGY

Portland State University

1975 
TO THE OFFICE OF GRADUATE STUDIES AND RESEARCH:

The members of the Committee approve the thesis of Teri Jones Geist presented February 14, 1975.

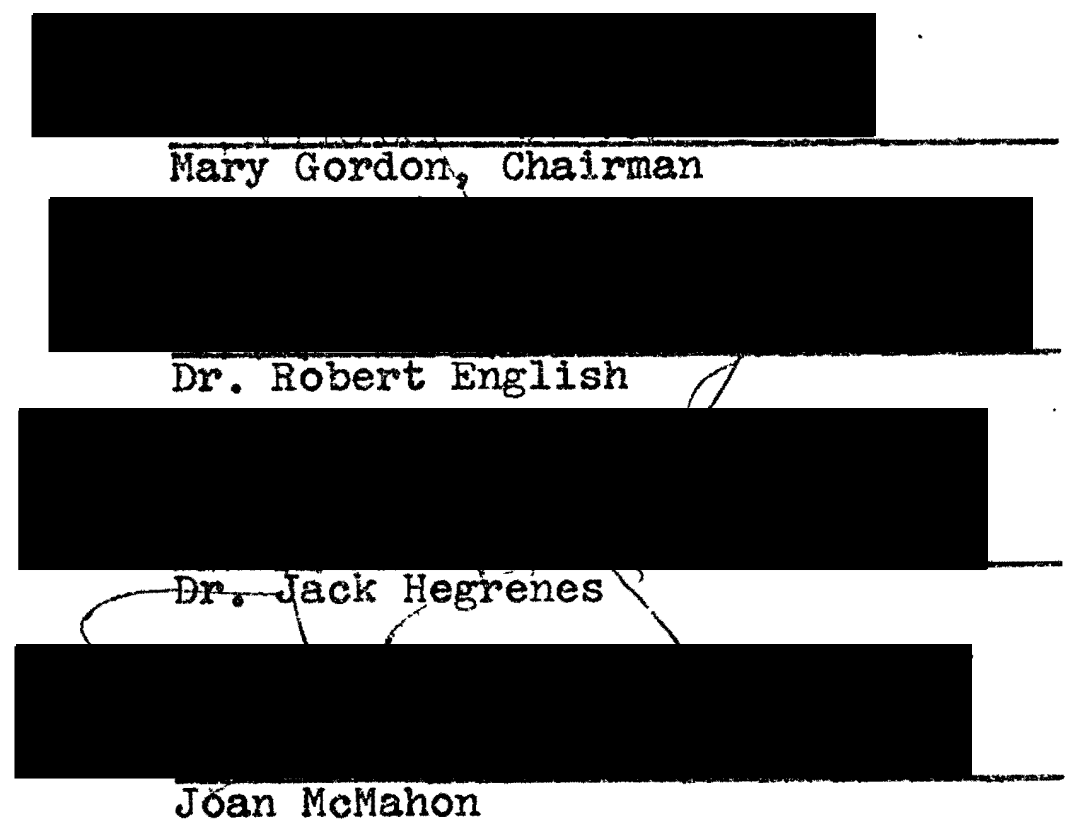

APPROVED:

Robert W. Vogelsang: Head, Deparytient of Speech Communication

David T. Clark, Dean of Graduate Studies and Research

February 14, 1975 


\section{ACKNOWLEDGMENTS}

Much gratitude and appreciation is extended to Mary Gordon, the chairman of my thesis committee. With her enthusiasm and assistance I was able to meet what seemed like rapIdly approaching deadlines. Many thanks, also, to two other members of my committee, Joan McMahon, for her ever-present encouragement, and Dr. Robert English, who enlightened my knowledge on the development of cognition. Appreciation and thanks, too, are extended to Dr. Jack Hegrenes, whose statistical assistance and expertise helped to make what I thought would be an impossible task really quite understandable.

Words cannot express the gratitude I would like to convey to my wonderful parents for their enduring support throughout my education. Finally, to my husband I say, thank you for everything; we made it! 
TABLE OF CONTENTS

PAGE

ACKNOWIEDGMENTS

LIST OF TABLES

IIST OF FIGURES

$\nabla 11$

CHAPMER

I INTRODUCTION AND STATEMENT OF PURPOSE • •

II REVIEW OF THE LITERATURE . . . . . . •

School Readiness . . . . . . . .

Language Development of the Lower-Class Ch1ld.

The Development of Cognition ......

Concept Developnent ........ 23

\section{III} METHODS AND PROCEDURES . . . . . . . .

Subjects . . . . . . . . 39

Variables ........... . 39

Grade Level

Auditory Acuity

Emotional Stability

Socioeconomic status

Instrumentation

Instruments

Test Administration

Date Analysis . . . . . . . . . 


\section{APPENDICIES}

A NUMBER OF CHIIDREN IDENTIFYING EACH CONCEPT CORBECTLY ON THE BTBC BY SOCIOECONOMIC IEVEL AND GRADE LEVEL . . . . . . . .

B AVERAGE VALUES FOR EACH THREE-MONTH INTERVAL BY SOCIOECONOMIC STATUS AND GRADE LEVEL ON THE BTBC ...............

C PFVT I.Q. SCORE AND M.A. AND BTBC RAW SCORE FOR EACH SUBJECT . . . . . . . 


\section{IIST OF TABLES}

TABLE

PAGE

I Approximate Age Levels when Certain

Concepts Are Acquired . . . . . . . 26

II Order of Appearance of Verbalized Concepts of Space ............. 28

III Trend of Development of Time Concepts

Throughout Preschool ...... . 31

IV Mean BTBC Scores and Standard Deviations

for the Number of Concepts Correctly

Identified for Each Group of Lower- and

Middle-Class Subjects at Each School . . 48

$V$ Values of T Relative to BTBC Raw Scores for

the Comparisons of the Subjects of Each

Socioeconomic Group in Each Grade

Between Schools . . . . . . . . 48 48

vI Mean Scores and Standard Deviations for the

Number of Concepts Correctly Identified

on the BTBC for Combined Kindergarten

and First Grade Groups . . . . . . 50

vII Mean Scores and Standard Deviations for the

Number of Concepts Correctly Identified

on the BTBC for Each Socioeconomic 
VIII T-Test Values for the Number of Concepts Correctly Identified on the BTBC ....

IX Mean Ages in Months, Standard Deviations and value of $T$ for the subjects in This study ............ 51

$\mathrm{X}$ Mean Scores and Standard Deviations for Each Concept Area on the BTBC by Grade Level . . . . . . . . .

XI Means, Standard Deriations, and Values of T for Each Concept in Four Comparison Groups on the BTBC ......... 


\section{LIST OF FIGURES}

FIGURE

PAGE

1.

Average Number of Space Concepts Correctly

Identified on the BTBC by Kindergartners and First Graders .......... 60

2. Average Number of Time Concepts Correctly

Identified on the BTBC by Kindergartners and First Graders ........ 60

3. Average Number of Quantity Concepts Correctly

Identified on the BTBC by Kindergartners and First Graders ...........

4. Average Number of Concepts Correctly Identi-

fied on the BTBC in Each of Three Categories by Kindergartners and Pirst

Graders .............. 
CHAPTER I

INTRODUCTION AND STATEMENT OF PURPOSE

\section{INTRODUCTION}

Several terms are used today to describe children who are members of the lower socioeconomic class in our society. Synow nymous terms include culturally disadvantaged, culturally deprived, socially disadvantaged, and underpriviledged. A common element, which seems to be found in all of these, is that chllören from lower socioeconomic status backgrounds lack the oppontumity to leann through experiences nonmally found in wat dle- and upper-class home environments which facilitate success in school (Bereiter and Engelmann, 1966; Havighurst, 1965). Bereiter and Engelmann (1966) asserted that in lower-class homes the cognitive uses of language are severely restricted between adults and their children, which impairs the ability to describe, Instruct, explain, test, hypothesize, deduce, compare, and analyze. These cognitive processes obviously are essential to school success.

One of the cognitive uses of language which is hindered in the lower-class child is the development of concepts. A concept, as defined by Arnone (1971), is a personal understandIng of a symbol, 1.e., a mental image; it has certain characteristics: 1) it is identifiable; 2) it can be learned, 
labelled, and forgotten; and 3) the acquisition of one concept can have a positive or negative effect on the learning of a second one. Concepts develop slowly from concrete to abstract and at different rates for different individuals (Arnone, 1971; Beed and Dick, 1968). An individual develops concepts through experiences in which he engages (Arnone, 1971; Reed and Dick, 1968). Differences in concept development do exist among aifferent socioeconomic or cultural groups. The disadvantaged child lacks the language facility which is necessary for independent thinking and problem solving (Doyle, 1972; Berelter and Engelmann, 1966). His deficit in language facility hinders his development of concepts (Doyle, 1972; Bereiter and Engelmann, 1966). An example of the phenomenon of differences in concept development among different socioeconomic or cultural groups can be illustrated by a study comparing Indian and nonIndian children, which found that the statistical differences in verbal concepts as measured by the Boehm Test of Basic Concepts were associated with differences in socioeconomic status or culture (Mickelson and Galloway, 1973). One study has been published which compared the responses of two different witite socioeconomic groups on this instrument; the experimental groups were urban and rural. This researcher, however, found no studles which compared the responses of two different white socioeconomic groups in an urban setting using this instrument. It is felt, therefore, that a need presents itself to determine if a statistically significant difference exists. 
II. STATEYENT OF PURPOSE

The purpose of this study was to compare the responses of white, midale-class kindergartners and first graders with white, lower-class kindergartners and first graders on the Boeho Test of Basic Concepts (Boehm, 1969). A secondary purpose was to determine if a significant correlation existed between concept development as measured by the Boehm Test of Basic Concepts and intelligence from an assessment of receptive vocabulary by using the Peabody Picture Vocabulary Test (Dunn, 1959).

The null hypotheses to be tested in this investigation were:

1. No statist1cally significant difference will exist betwoen the total number of concepts conrectly identified by: a) the Jower-class kindergartners and the middle-class kindergartners; b) the lower-class first graders and the middleclass first graders; c) all lower-class and all middle-class subjects; and d) all kindergarten and all first grade subjests. 2. An analysis of the conceptual areas of space, time, and quantity will reveal no statistically significant difference between the number of concepts correctly identified in each area by: a) the lower-class and middle-class kindergartners; b) the lower-class and middle-class first graders; c) all lower-class and all middle-class subjects; and d) all kindergartners and all first graders.

3. No statistically significant relationship will exist between scores earned by all subjects on the Peabody Picture 
Vocabulary rest and those scores earned by all subjects on the Boehm Test of Basic Concepts. 


\section{CHAPTER II}

\section{REVIEW OF THE IITERATURE}

For the purpose of the present study, a review of the 11terature relative to cognitive language development in children will center around four areas: 1) signs of school readiness relating speciflcally to which concepts should be possessed by a chlld previous to school entrance; 2) language development, chiefly of the lower-class child; 3) the development of cognition in children; and 4) the process of concept develocment in children.

\section{SCHOOL READINESS}

The concept of school readiness has been surrounded by more controversy than any other topic in education (Beller, 1970). The controversy seems to have at its base aifferent Ideas of determining when a child is ready to learn. Beller (1970) cited several educators who have held differing positions on school readiness. One such viewpoint is Rousseau's concept of readiness which was based on maturation. He, reportedly, criticized educators for not waiting for the necessary faculties to "ripen" in the child (Beller, 1970). Gesell's school of readiness was stated to be more interested in biologlcal speculations about developmental changes in behavior than in behavioral changes resulting from an individual's 
interaction with his environment. Gesell did not totally ignore the environment, however; he felt that environmental factors may influence a child's developmental sequences, but the basic foundation was laid by biological factors. Similarly, IIg and Ames, who worked with Gesell, were reported by Beller (1970) to attribute changes in development to blological phenomena; environmental factors such as ethnic background, social class, and other environmental influences do not play an influential role in the determination of readiness. For IIg and Ames, true readiness was said to be based on detalled observations of what children actually do under "normal circumstances" (Beller, 1970).

Beller (1970) felt the concept of readiness should be objectively defined, as he wrote:

Statements concerning readiness become more meaningful in the sense of being testable, when criteria of readiness are pinned down to specific activities or operations in such a way that their relationship to rate of learning and level of achievement of new activities or operations can be ascertained and in some way predicted.

Lee and Lee (1958) specified some considerations which have implications for the determination of a readiness to Iearn:

1) there exist in a child's life developmental perlods when readiness for certain learning is at its optimum;

2) the chtld's readiness to respond to school tasks is greatly affected by the home environment;

3) one aspect of development may influence other factors;

4) the "emotional climate" of the home is of utmost importance:

5) an individual child's abilities vary greatly; and

6) maturation and learning both contribute to readiness. 
In addition to these implications, they felt that a child's readiness to learn depends on a number of factors influencing his development; among them are motor development, development of self-concept, intelligence, the child's relationship with himself and the child's relationship with others (Lee and Lee, 1958).

Several researchers have commented on signs of school readiness. Behrmann (1972) enumerated certain questions to be considered in determining if a child is ready for school: 1) Does the child have a sense of time?; 2) Does he know left from right?; 3) Does he know the days of the week and months of the year?; 4) Does he understand the common words or phrases used in school, such as second, next to, and after?; 5) Can he follow directions? An examination of these questions reveals that some type of conceptualization is involved in each. Sim11arly. Locatis and Smith (1969) have stated that certain skills are a prerequisite for children entering the first grade, and without them children fail. Among these skills is a knowledge of basic concepts which is essential to learning in subsequent grades.

There seems to be a paucity of research detailing exactly what concepts children should know before entering school. Lee and Lee (1958) have stated that relatively little is known pertaining to the age at which it is possible for children to understand certain phases of various concepts. The concepts emphasized in the literature as having a bearing on readiness for learatng are knowledge of color, names of animals, concepts 
of space, size limitations and money, time and place orientation, knowledge of geometric shapes and the position of objects in space. The ability to perceive differences in objects and geometric forms is thought by Gulridge (1953) to be a signal for being ready to read.

Most children reflect a readiness to enter school. It has been stated, however, that lower-class children are def1cient in the ability to master the cognitive uses of language, which is a disabllity that can cause them to be as much as two years behind their peers upon entering school (Bereiter and Engelmann, 1966). By the time most lower-class children reach school, they are already behind their middle-class peers. Berelter and Engelmann (1966) have emphatically stated that the retarded language development displayed by lower-class children will prevent them from achieving academic success in 80hool. Deutsch (1966) has noted that children from disadvantaged backgrounds, on the whole, enter school with a somewhat different language system than middle-class children. Thetr language systems appear to be simpler in syntax and less rich in descriptive terms and modifiers than is the language of the average, middle-class child.

Data suggest disadvantaged children suffer in the areas of perception, verbal skills, and attention (Deutsch, 1966), 1.e., areas which represent crucial, underlying skilis in school learning. In addition to these areas, Breshnahan and Shapiro (1972) felt the specific areas in which children from lower-class environments are deficient are reading, number 
concepts, time concepts, auditory discrimination, visual discrimination, and symbolic representation. Since so many lowerclass children are lacking in the crucial areas necessary for school success, one might say they do not display the academic skills necessary for school entrance as do other children of the same chronological age.

These children are headed for fallure unless a rapid "catch-up" process is provided. Several individuals have of fered suggestions relative to educating the lower-class child and helping him develop the cognitive uses of language in order to facilitate success in school. Biber (1967) outlined four kinds of essential experiences for the five-year-old child who is beginning school. She stated the lower-class child should: 1) have an extended opportunity to explore the physical world; 2) be helped to become increasingly sensitive to the world in which he lives; 3) have a full opportunity for "doing and making"; and 4) have support in his developmental tendency to deal with things indirectly, to symbolize them and to reproduce in his own particular way experiences that have been meaningful to him. As a supplement to this, Doyle (1972) stated that the disadvantaged child: 1) must be taught how to manipulate words into meaningful thought processes; 2) must learn differences in size, shape, and color; 3) must learn to classify and group things; and 4) must be made aware of tactile differences of soft, hard, rough, and smooth.

In summary, our educational system is based on conceptual 
learning (Doyle, 1972). The ability to master the cognitive uses of language has been said to be a determining factor for a child to achieve success in school. As a result of the lower-class child's inability to master the cognitive uses of language, he may meet failure in school unless he is involved in a rapid "catch-up" process.

II. IANGUAGE DEVELOPMENT OF THE LOWER-CLASS CHILD

A brief examination of the language development of the lower-class child may offer insight into reasons why his language development does not adequately prepare him for school. The normal development of language is a process of refinement and growth. In most children (after the age of three years) the rocabulary increases and sentence structures become more complex. The environmental factor of economic status and cultural deprivation is highly correlated with language development. The language spoken in the homes of lower-class ch1ldren seems to be typically poor in quality and quantity (Bloom, Davis, and Hess, 1965). Conversely, McCarthy (1930) has found that children from "superior" socioeconomic backgrounds will be superior in speech and language, with superiority most of ten being related to differences in the educational level of the parents.

Schterelbusch (1967) has stated that the acquisition of language by the lower-class child is inhibited by two factors: 1) minimal social interaction; and 2) a lack of sufficient reinforcement. It would appear that a crucial relationship 
exists between verbal interaction and language development. Merely stimulating a child verbally is not enough; in addition, a child must interact with adults. In examining this hypothesis, Neal (1967) found that verbal interaction is often absent from lower-class homes. Because of the lack of verbal interaction between children and adults in lower-class homes, the children learn language by means of receptive exposure, 1.e.: by hearing rather than by the correction of their own speech. Children in midale socioeconomic homes learn their language by feedback, 1.e., by the correction and modification of their own speech. More explicitly, adults in middle-class homes, characteristically, tend to use words so freely and easily they teach them to a child at almost every opportunity (Bloom, Davis, and Hess, 1965). The following process is involved: encouraging the chlld to say the word aloud; correcting him when he says the word incorrectly or wrongly applies it; and reinforcing him when he uses a word or symbol correctly. The culturally advantaged child appears to have more access to this correctIve feedback than other chllaren.

According to Schiefelbusch (1967), the second factor which inhibits the acquisition of language by the lower-class ohild is a lack of sufficient reinforcement. Encouragement to talk and corrective feedback reinforcement are abundant in most middle- and upper-class home environments. Too often, the lower-class child's attempts at verbal communication are followed by negative reinforcement such as "Shut up," "Be quiet," or "Don't talk until you've been spoken to," which is grammaticaliy 
incorrect in and of itself. Additionally, he is corrected and 1s fed misinformation in the process. Consequently, the lowerclass child has learned through trial and error that iittle verbalization is quite compatible with his environment, and as Wicker (1972) has stated: "Most of the time, most people behave in ways compatible with their environment."

Several others have commented on the language retardation of lower-class chlldren. The language deflclencles pospessed by lower-class children have been attributed to several Pactors; among them is the lack of social experiences in the lower-class child's home which seems to be the crucial factor relating to his fallure to develop cognitive language (Brottman, 1965; Engelmann, 1966; and Deutsch, 1967). Disadvantaged children often are not exposed to situations which provide experience with cognitive skills. These situations have been outlined by Havighurst (1965) as a family environment which sets examples of reading, and one which provides a variety of toys and play materials of varying colors and sizes, posing a challenge to the child's ingenuity. A second situation is a family conversational experience which encourages the child to ask questions, answers his questions, and extends his vocabulary with new words.

The ways in which parents spend time with their children at meals, in play, and at other times during the day have been found to be central factors in developing skills which prepare children for school (Bloom, Davis, and Hess, 1965). Engelmann (1966) and Deutsch (1967) have stated that the activity of the 
chlld's environment and his capacity to learn form a very firm relationship. The child's capacity to learn follows the activity of his environment, as it is the active verbal engagement of people surrounding the child which is the operative influence in the child's language development. Most disadvantaged children spend less time in direct interaction with their parents than do middle-class chtldren. Bloom, Davis, and Hess (1965) found that a difference definitely exists between the amount of time spent in direct interaction between parents and children in middle-class home environments and that between parents and children in lower-class home environments. Usually, parents in lower-class homes do not have the skills in language to effectively use the time they spend with their children in order to foster the language and cognitive development that would help the child in school.

In conclusion, then, it can be said that one factor that seems to account for the lower-class child's retarded cognitive development is the minimal amount of stimulation and reinforcement experienced in the environment in which he spends his preschool years.

\section{THE DEVELOPMENT OF COGNITION}

Cognition has been defined in many ways, and these definitions have carxied with them several speculations about the development of cognition. Minor (1973) defined it as: ". . the process by which the organism acquires, stores, and utilizes Information," while Phillips (1969) characterized cogni- 
tive development as ". . the process of selecting, discovering, and maintaining thought." Ellis (1972) felt this process involved such activities as thinking, reasoning, problem-solving, and conceptual learning. In reviewing the literature on cognitive development, it appeared to this investigator that psychologists and others who have studied intelligence indicate that cognition can only be inferred, i.e., the symbolic and mental processes involved in cognition are not directly observable. They are inferred from behavioral changes. Theories of the development of cognition seem to be based on inference. One of the most noted researchers of cognitive development in children, Piaget, formed his theory from extensive observations of the behavior of children and adults; he noted the child's surroundings and his behavior in those surroundings (Philiips, 1969).

Cognition has been considered to be one component of intellectual functioning. Guilford (1956 and 1961) theorized that intellectual factors are categorized into two major groups: 1) thinking, and 2) memory. The great majority of inteliectual abilities are thinking factors. Thinking abilities were subdivided further into cognitive, productive, and evaluative abilities. Cognitive factors deal with the development of awareness of information and the recognition and remembering of this information. Productive abilities enable a person to act with this information. Evaluative abilities are utilized wher It is necessary to determine the suitability, adequacy, or effectiveness of the results of thinking. Memory, the 
second component of intelizgence, is the retention and recall of information (Guilford, 1956). Guilford (1959) classified Intellectual factors according to the kind of material or content involved. He proposed three kinds of material: 1) figural content or "concrete material such as is perceived through the senses, and which does not represent anything except itself,"e.g., size, and color; 2) symbolic content which is composed of letters, digits, and other conventional 8igns; and 3) semantic content which takes the form of verbal meanings or ideas.

Several researchers have delineated components of cognition. Ellis (1972) divided cognition into the processes of thinking, reasoning, problem-solving, and conceptual learning. All of these processes were thought to be a part of learning, or the acquisition of new information.

According to Kagan (1971), however, an individual must possess a set of mental structures before he can learn. Schemata, images, symbols, concepts, and rules compose these mental structures, which give substance to thought. He attributed much importance to these structures stating:

1) They are the bricks and mortar of the larger structure called intelligence.

2) These structures are not located in any one place in the mind; nor do they have substance or physical dimension.

3. They are served by a set of cognitive processes which include perception, memory, evaluation, generation of ldeas and reasoning. The interactions of these mental processes define thought.

Kagan described each of these mental structures. The schema - . Is a representation of the critical features of a 
specific event" and may be the earliest acquired of the structures. An image is more easily manipulated in thought and is defined as ". . a detalled and elaborate mental picture created from a schema."

The best way to regard the relationship between a schema and an image is to view the former as the basic skeleton from which a complete and elaborate representation is built when cognitive processes perform on the schema (Kagan, 1971).

Symbols are ". . artitrary names for things and qualities." In contrast to schema, a symbol is an arbitrary way to name a thing; a schema is not arbitrary, but represents the features of a specific event. A concept stands for a common attribute among a group of schemata, symbols, and images. The main difference between a symbol and a concept is that the former stands for one object or event, while a concept represents something common to several objects or events. Concepts will be discussed further in a later sub-section of this chapter. Rules involve a set of procedures that effect a relation and or state a simple relationship between two concepts. These Iive mental structures enable an individual to think and solve problems (Kagan, 1971; and Ell1s, 1972). Experiences the child meets as he is solving problems enrioh and strengthen these mental structures (Kagan, 1971). This investigator found the importance of experience in a child's Iife consistentIy emphasized by authorities who have written about the development of cognition and concepts.

Additionally, Kagan (1971) has outlined the sequence of events in problem-solving and stated that the major processes 
involved are comprehension, memory, generation of 1deas, evaluation, implementation, and occasionally reporting. These processes enumerated by Kagan coincide with some of Guilford's (1956 and 1961) processes outlined above. The child must first comprehend the problem, that is, his perception and interpretation of the problem must be accurate. The interpretation of events in the child's environment almost always takes place, but the form of interpretation changes with age. Kagan (1971) further contends that the infant or very young child usually translates experiences into schemata or Images, but when he ts older he will rely more on symbols and concepts. This change is thought to take place around five to seven years of age, and results from the ability of the child to focus his attention on more than one event at a time. The second problem-solving process, memory, allows the child to store information in order to solve a problem. A child under six or seven is able to hold only a few words or ideas in his mind if someone is speaking to him; his long term memory also is not as well developed as it is in preadolescence (Kagan, 1971). There are two major reasons for the young chlld's poorer memory: 1) the young child has not developed the language which enables him to label an event, in other words, the use of schema, Images, symbols, concepts, and rules to label helps an individual hold the event in his memory; and 2) the child has either not yet learned or does not wish to use the device of rehearsal, i.e., spontaneous repetition of events to oneself in order to hold them in memory for later retrieval. The 
third process in problem-solving is the generation of possible solutions, including the development of alternate ways to solve a problem. Kagan (1971) described three steps involved in the generation of solutions. First, the child searches his set of mental structures, especially his concepts and rules, for possible causes of an event that he does not immediately understand and then generates several explanations. Secondly, the child checks these explanations for consistency with his older rules about the event. If his explanation is in disagreement or contradicts an older rule which the child belleves more strongly, he will probably reject the new explanation. Last1y, If the child finds an explanation that matches his experlence and is not in disagreement or does not contradict an older rule, he will probably accept it as correct. After the generation of possible solutions to a problem, the child evaluates thew. The final step in the problem-solving process is implementation which is the deduction of a conclusion from an idea that has been generated. The generation of an idea and deduction of a conclusion are the two cognitive processes which are regarded as the essence of thinking (Kagan, 1971). Cognitive development is in ongoing process, and takes place in the chlld's life throughout infancy, childhood, and adolescence (Smart and Smart, 1967). The development of cognition has been seen from basically three positions, as outIined by Cooke and Cooke (1973) and Pines (1967). Cognitive theorists, including such authorities as Plaget and Montessor. view thought as developing from the organism-environment 
interaction. They are concerned with how young children learn to think and how best to help them. Cognitive theorists believe that the lives of all children could be made much richer if their abilities were developed systematically from birth. Conversely, Gesell and other maturational theorists have described the development of children through extensive observat1ons. Developmental changes are considered to be "embryological," i.e., a stage represents the total state of an organism at any given time. Behavioral theorists, chiefly Skinner, see the environment as a source of energy, which is directly or indirectly transmitted to the child through his interactions with the environment. The child's function in the environment is to emit observable behavior. Opportunities in the child's past and future development are responsible for his progressive derelopment.

The early years of a child's life are important ones because learning proceeds more rapidly between the ages of birth and four than during any other comparable perlod of time in the child's life (Yardley, 1973; and Pines, 1967). Yardley (1973) has stated that both physical and mental growth rates start fast, peak between four and five years of age, and then begin to decelerate. She also speculated about the ages at which certain cognitive skills are developed. Between birth and four years, 50 percent of one's intelligence develops; whereas, 30 percent is developed between four and eight and 20 percent between eight and seventeen. Approximately 33 percent of the ehild's academic skills are attained before he is 
s1x; 42 percent, between six and thirteen; and 25 percent, between thirteen and elghteen (Yardley, 1973).

The onset of expressive language and a rapid increase in the comprehension of speech marks an important stage in cognitive development. The development of language allows the child to learn through verbal mediation, thus, giving him more resources to solve problems (Smart and Smart, 1967). Kagan (1966) felt the most important development during this time is the growth of a labeling vocabulary. He stated that, with labels, the child acquires a set of symbols that allow him to categorize and conceptualize aspects of his environment which Smart and Smart (1967) felt enable him to have control over 1t.

The preschool child around four years of age shifts from a functional-relational basis for categorizing to an analytic or categorical one (Kagan, 1966). Instead of viewing an orange as only something to eat, he is now able to classify an orange as an object with skin or as a pruit. During his first four years of life a child has interacted with other people and has had many experiences which have enabled him to develop the cognitive skills necessary for logical thinking (Smart and Smart, 1967).

A further expansion of the child's cognitive skills occurs during the years from five to ten (Kagan, 1966). Two basic cognitive processes surface in the early years of school: 1) the growth of rules for transformations; and 2) the growth of the ability to evaluate. 
In most children the development of cognition proceeds in an orderly, predictable manner. Their environment provides them with experiences necessary to the development of cognitive functioning. For disadvantaged children, however, the exposure to situations which provide experience with cognitive skills is not present (Brottman, 1965). The progressive development of the disadrantaged child is hindered because of the lack of opportuntties in his environment; the faulty learning in the disadvantaged child is the product of a faulty environment not a faulty child (Cooke and Cooke, 1973). Cognitive psychologists assume that children who are deprived of early intellectual stimulation will never reach the heights of which they might be capable (PInes, 1967).

Smart and Smart (1967) stated the key part of cognitive growth is the acquisition of language, and any child who does not acquire adequate verbal symbols and who does not use then in thinking becomes retarded intellectually. Similarly, Blank and Solomon (1969) directly related the lack of a symbolic system for thinking in the disadvantaged child to his deficient Ianguage. Bnmerich (1973) found that children less advanced in rerbal knowledge were least likely to engage in cognitive skills in the classroom. Several other researchers have studled cognitive functioning in disadvantaged children. Wallace (1965) administered a number concept test to 250 children between the ages of five and nine, who were from three different socioeconomic groups. The results of this test did not reveal significant differences although the test scores were somewhat 
higher in the upper socioeconomic groups. This led him to suggest the home environment may be important in the development of number concepts in children, and children whose environment was more stimulated tended to show a real understandIng of numbers. Wulff (1974) studied the ability to draw inferences and to make generalizations in disadvantaged and advantaged students. He concluded from his data that learning styles of the disadvantaged students seemed to indicate they are less able to draw inferences and to make generalizations than are advantaged students. Meissner and Shipman (1973) found a higher level of information-processing skills and conceptual understandings among Head Start preschoolers who were members of the middle and upper socioeconomic classes. Golden and B1rns (1971) found no differences among infants between eighteen and twenty-four months of age on an object test. They conoluded that differences in intellectual development or cognitive style attributable to differences in socioeconomic status emerge somewhere between eighteen and thirty-six months of age when language is developed.

Yardley (1973) felt the parent is responsible for the emotional environment in which the growth of the mind takes place. She also stated the time to provide the child with help is before he enters school, since one-third of his ultimate intellectual skills will be mastered by $s i x$, and the growth of the brain is largely completed by age seven. When the disadvantaged child gets to school cognitive psychologists urge teachers to ". . arouse the sluggish brains of children raised 
by parents too poor, harried, or ignorant to teach them much that was relevant to school" (Pines, 1967).

By way of review, we have noted in this section that cognition is composed of several factors which are developed in an orderls, predictable manner, and is constantly growing as the child meets new experiences. Because experiences are essential in the child's development of cognitive functioning, he needs inteliectual challenge from his earliest years (Yardley, 1973). The lack of stimulation the disadvantaged child recelves may retard the development of intelilgence, thus, providing a poor preparation for school.

\section{CONCEPT DEVELOPMENT}

In the previous section concepts were stated to be an essential component of cognitive development and a component of the mental structures an individual must possess before he can learn. This section will expand on conceptual development, since a knowledge of concepts has been found to be essential to success in school.

Several researchers have studied conceptual development in children. Ward (1957) felt the extent of the understanding of meanings of words, as well as the ability to use them effectively in thought and communication, depends on the completeness and comprehenstveness of experiences through which that meaning is built. Experiences have been stated to be necessary for the development of language, and so too, are they necessary for the developnent of concepts. Ward (1957) 
has stated that it is through experiences that an inditidual develops concepts. Similarly, Lee and Lee (1958) have commented that it is very important that a learner discover for himself the concept and its relation to others. To enhance his discovery, observation and self-discovery are required In the child's 11fe. In a lower-class home, these opportunities of ten are not present; hence, the child's development of concepts may be impaired.

Arnone (1971) defined a concept as ". . a personal understanding of a symbol, i.e., a mental image ..." while Tennyson (1972) defined concept acquisition as "... the ability of the learner to correctly identify previously unencountered objects or events as members or nonmembers of a particular concept class." A child demonstrates that he has a concept of a word when he applies a word to a group of objects or events (Smart and Smart, 1967). Kagan (1971) saw concepts as part of an individual's mental structure which enable him to acquire new knowledge. A concept stands for characteristics of events, not for a particular event, and represents those attributes that are common to a collection of experiences. Kagan (1971) identified four important qualities of a concept: 1) degree of abstraction; 2) complexity, 1.e., the number of dimensions necessary to define it; 3) differentiation, i.e., ". . the degree to which the basic set of common qualities it represents can assume varied but related forms that describe slightly different versions of the idea"; and 4) centrallty of dimensions, i.e., the number of central 
dimensions required for one to derive meaning from a concept. The major areas of conceptual development have been stated to be: 1) properties, i.e., what is it like; 2) positional, 1.e., where is 1t; 3) opposites; 4) quantification, 1.e., how much is it; 5) comparisons; 6) association, i.e., relations and 1deas; 7) time; and 8) motion, 1.e., how does it move (Mann, 1972).

There are two different types of concepts, concrete and abstract (Kagan, 1971; and Doyle, 1972). Concrete object concepts refer to objects readily perceptible in the environment, such as, food and furniture. Those concepts with referents not directly perceptible, are abstract concepts. Examples of the latter are time, space, causality, and emotion. Kagan (1971) explained that a concept whose dimensions are close to experience is said to be concrete, while concepts whose dimensions refer to events that cannot be pointed to or experienced directly are sald to be abstract. Moerk (1973) felt abstract concepts are based on sensory-motor interaction with the environment. The first concepts a child develops are concrete; abstract concepts are developed through repeated experiences, especially those verbalized by other people in certain ways (Smart and Smart, 1967). Abstract concepts are the most difpicult to learn because of the necessity to include such large amounts of generalization when trying to abstract. Because of their retarded language development, lower-class children experience much difficulty with the cognitive function of abstracting. 
This investigator found little evidence in the literature relative to the ages when children derelop certain concepts; however, Engelmann (1966) felt that the concepts a child learns before his fifth birthday are among the most difficult he will ever encounter. He also stated that evidence of potential giftedness in the normal child is offered by the concepts he learns during his preschool years. Although not definite developmental levels, Engelmann (1966) provided a timetable durIng which certain concepts are acquired (Table I).

\section{TABLE I}

APPROXIMATE AGE LEVELS WHEN CERTAIN CONCEPTS ARE ACQUIRED

\begin{tabular}{ll}
\hline Age in Years & Concept \\
\hline 1.6 to 3.0 & comparative words \\
1.6 to 3.0 & position relations \\
1.6 to 3.0 & geometric relations \\
3.0 to 4.0 & time \\
3.0 to 4.0 & between \\
3.0 to 4.0 & right and left \\
3.0 to 4.0 & before and after \\
3.0 to 4.0 & new and old \\
3.0 to 4.0 & same and different \\
3.0 to 4.0 & first and second \\
3.0 to 4.0 & today, tomorrow and \\
& Jesterday \\
\hline
\end{tabular}

The development of the concepts of space, time, and number has been studied by several individuals (Ames, 1946; Gesell and IIg, 1946; Ames and Learned, 1948; Boehm, 1967; Smart and Smart, 1967; and IIg and Ames, 1972). Space is composed of many dimensions which are indicated by prepositions and 
adjectives, e.g., "on," "under," "in," "above," "in front of," "behind," "high," "low," "thin," "thick," "vertical," and "hor1zontal" (Gesell and Ilg, 1946). The concept of space develops through sensory-motor experiences with the environment (Gesell and IIg, 1946; and Smart and Smart, 1967). During the early part of his development of spatial concepts, the child relates space to his body, but as he grows older he begins to devote more attention to information he receives from adults (Smart and Smart, 1967). GeselI and IIg (1946), Ames and Learned (1948), and IIg and Ames (1972) have offered a table showing the development of concepts of space (Table II).

Yardley (1973) stated that space is perhaps the simplest problem with which a child has to deal. Gesell and Ilg (1946) felt the five year old's chlef spatial interest is in what is here, 1.e., he's extremely focal, being interested in the space whlch he Immediately occupies. The child possesses little insight into geographic relationships. The extreme interest in "hereness," which is possessed by the five year old, has been expanded in the six year old. Gesell and IIg (1946) noted the six year old is not only interested in specific places but in relationships between home, neighborhood, school, and community. The seven year old, reportedly, is quite interested in space with regard to his place in the world (Gesell and.IIg, 1946).

Time concepts were thought by Smart and Smart (1967) to originate with experiences of bodily rhythm, 1.e., sensations the infant receives on a predictable schedule such as hunger, 
TABLE II

ORDER OF APPEARANCE OF VERBALIZED

CONCEPTS OF SPACE

Months

12 Wriggles for "down;" gestures for "up"

15 Says "up"

18 Says "down," "off," "bye-bye," "all gone," "come," "go"

21 Say:s "on," "big," "here"

24 Says "up high," "In," "out there," "where," "go way, "fall down," "turn around," "other side," "all gone," "here." Interest in coming and going.

30 Uses rigid, exact space words: "right," "right here," "right there," "right up there," "up high," "home," "to," "around the table," "under the table." Words combined for emphasis and exactness; "way up," "up in," "in here," "in there," "far away." "In," "up," "on," "at," used most.

36 Begins to show interest in concepts of "left" and "right." Befinements of space perception: "back, "corner," "over," "over here," "from," "by," "up," "on top," "on top of," "gone away." Interest in detail and direction: tells where his daddy's office is; where his bed is; uses names of cities. Carries out commands in regard to "over," "crooked, "under," "big," "high," "long," "under," "on."

42 "Next to," "under," "between." Interest in appropriate places: "go there," "find." Interest in comparative size: "littlest," "bigger," "largest." Expanding interest in location: "way down," "way off," "far away." Puts the ball "in," "on," "under," "in back of the chair."

48 More expansive words: "on top of," "far away," "out in," "down to," "way up," "way up there," "way far," "out," "way off." The word "behind." Tells his street and city. Puts a ball "In front of," "behind, a chair. Words used most, "in," "on," "up," "at," "dow."

60 Carries out commands in regard to: "few," "forwards," "backwards," "tiny," "smooth," "high." Interest in space, but not in spatial relations.

72 Distinguishes "left" and "right" on own body, but not on others; spatial concepts relatively undifferentiated. 
TABLE II

ORDER OF APPEABANCE OF VERBALIZED

CONCEPTS OF SPACE

\section{(continued)}

Months

84 Still cannot distinguish "left" and "right" except in reIation to own body. 
eating, and fullness. The concepts of time and space are closely related, with many of the words used to describe time also used to describe space, e.g., "long and short," "near and far," "here and now," and "there and then" (Gesell and IIg, 1946). The concept of time appears to be more abstract than space; 1.e., It cannot be found to possess as many sectors as space, and does not change as much as space does. Time moves "forward" or "backward," whereas space moves "in," "on," "under," "there," "here," "in front of" and in many other directions. Smart and Smart (1967) found time and space are not differentiated until beyond childhood; however, as a child matures and encounters experiences, he becomes more able to laentify time. His abilities to expect, defer, and manipulate time improve (Smart and Smart, 1967).

Gesell and IIg (1946), Ames (1946), and IIg and Ames (1972) presented a sequence of development of the concept time which is presented in Table III. Yardley (1973) commented that time is a difficult concept to learn, and remains at a very elementary stage in development during the first year in school.

Early, concrete experience, reportedly, serves as a basis for number concepts along with concepts of time and space (Smart and Smart, 1967): Three developmental stages in number conception were described by Smart and Smart (1967) for Beventy-two children between the ages of four and seven:

1) Preconceptual. Number is responded to in conceptual terms. When the arrangement of objects is changed, it may change perception of number. 
TABIE III

TREND OF DEVELOPMENT OP TIME CONCEPTS

THROUGHOUT SCHOOL

Months

18 Child I1ves in present; some sense of timing, but no words For time; finds it difflcuit to wait; attends to here and now; little perception for far of $f$ objects and events; no need to talk to him about the future; responds to "now."

21 Uses "now." Waits in response to "just a minute." Sense of timing improved, but continues to live in the present. May rock with another child, or sit and wait at the table.

24 Still lives in present; begins to use words to denote future; waits in response to "wait;" "pretty soon;" uses "going to" and "In a minute;" "now;" "today;" no words for past, but may use past verb tenses incorrectly.

30 Free use of several words implying past, present, and future, such as "morning;" "afternoon," "some day," "one day," "tomorrow," "last night." More future words than past woras.

36 Talks nearly as much about past and future as about the present. Duration: "All the time;" "all day;" "for two weeks." Pretends to tell time. Much use of the word, "time;" "what time?" "it's time," "Iunchtime." Tells how old he is, what he will do tomorrow, what he will do at Christmas.

42 Past and future tenses used accurately. Complicated expressions of duration: "for a long time," "for years," "a whole week," "in the meantime," "two things at once." Refinements in use of time words: "it's almost time;" "a nice, long time;" "on Fridays." Some confusion in expressing time of events: "I'm not going to take a nap yesterday."

48 Broader concepts expressed by use of "month," "next summer," "last summer." Seems to have clear understanding of sequence of dally events.

60 Concerned chiefly with now; more common time words used by adults are now a part of child's rocabulary and he handles them freely. 
TABLE III

TREND OF DEVELOPMENT OP TIME CONCEPTS

THROUGHOUT PRESCHOOL

\section{(continued)}

\section{Months}

72 Increasing knowledge of duration; shows little interest

in learning to tell time beyond the hours.

84 Sense of time becoming more practical, detailed and sequential; telis time by clock by hours and minutes; aware of time from month-to-month, season-to-season, and in terms of jears. 
2) Individual numbers are responded to in conceptual terms. The verbal terms are very helpful here in achieving concepts.

3) Relationship among the individusl numbers is understood.

In the early stages of number conception a child may count a number of objects one-by-one and state that there are, for example, seven apples; this represents a concrete number concept. As the child matures, he is able to abstract, and without counting one-by-one, is able to say there are seven.

During the preschool years the concept of all is developed and is fully conceptualized around five years of age (Smart and Smart, 1967). In the early stages of number conceptualization, the concepts one, some, and all are generalized to many situations (Smart and Smart, 1967). As the child meets experiences and observes the use of these concepts from others in his environment, he learns the correct uses of these concepts. The inability to abstract that children under five experlence was demonstrated by Smart and Smart (1967). They presented several preschoolers with two series of trays that contained: a dog and a bird; a dog and a pig; a dog and a cow; and a dog and a sheep. Although every child recognized each tray had a dog, fer children under five expressed the fact that all trays contained dogs.

Several other researchers have also speculated about the age at which children develop certain concepts. Bohles (1971) designed a study using four series of seven problems each consisting of $3,5,7,9,11,13$, and 15 blocks. He administered the problem to 402 male and 381 female children between the 
ages of three and thirteen. The task required the chlldren to select the midale block. Results showed the ability to select the middle block began to emerge at the three year level, developed rapidly through year six, and became fully developed by year eight. Similarly, Tsai, Chun-Wei, and Chien (1968) found the concept of "middleness" is not well developed among preschool children between the ages of two and live. As the child's age increases, however, his scope of conceptualization is expanded to the point that when he reaches school age he is beginning to master the concept of "middleness." Palermo (1973) found four and five-year old children performed better than three year olds on tasks requiring them to identify a lesser amount of something; whereas, three-, four-, and fiveyear olds performed equally as well among themselves with response to tasks involving the concept of more. The concept of more was known by more children than the number of children knowing each of the concepts same and less.

Maratsos (1973) studied the understanding of the word big in thirty-three, four and fire year olds, and concluded children around three years of age do not have a meaning for big which is tied to the vertical dimension. To the three year old, big meant overall size. Conversely, the four and five year olds defined big almost without exception as referring to the greater extension along the vertical dimension. Sowe children from four-and-a-half to five-and-a-half were able to judge size in terms other than height, as they gave the word "heary" as a response to one of the stimulus items. 
The researcher suggested this problem may be a semantic one with the terms big and tall being equated (Maratsos, 1973). From his observations, he suggested that to children of these ages big refers to height because when parents speak of their "big" child they usually mean "tali."

Differences in concept acquisition have been found among socloeconomic groups. Boehm (1967) found socioeconomic status, race, and age may be equally important influences on the attainment of concepts. She designed a study to describe the development of comparative concepts in primary grade chilaren relative to age, grade, socioeconomic status, race, predominately integrated and segregated school conditions, sex, and intelligence. Her subjects were 1,286 pupils in grades kindergarten through third. The results of her study showed the development of comparative concepts is related not only to age/grade, but also to school conditions, race, IQ, and occupational levels of parents. Her third grade pupils from the lowest occupational levels obtained mean scores similar to kindergarten pupils from the higkest occupational levels.

Houck, Blskin, and Regetz (1973) used the Boehm Test of Basic Concepts to compare the performances of urban and rural kindergartners and first graders. The rural subjects came from a county in Appalachia. In the urban and rural groups, the children were further subdivided into socioeconomic groups based on the father's occupation and level of educational attainment. The results of their study showed virtually no differences between the reliability coefficients of the lower- 
class urban and rural kindergartners. Signiflcant differences, however; did exist between urban and rural middle-class kindergartners and urban and rural middle-class Pirst graders, with the urban childrens' reliability coefficients the elevated rigures. Although these results do not show differences among socioeconomic groups, they do reflect differences in home environments.

Thomas (1966) studied the conceptualization of thirty, white advantaged children and thirty, white disadrantaged children as demonstrated by their performance on an object sorting test. The children were to classify their responses into four subdivisions according to use, situation, category, and physical characteristics. The results showed the concept beharior of disadvantaged subjects was of a "lower quality" than that of advantaged subjects; the disadvantaged children were not as able to conceptualize and classify their responses as the advantaged children.

Wasik and Wasik (1972) administered an instrument entitled the Concept Assessment Kit-Conservation to 117 children in an ungraded primary school for culturally disadvantaged children. This kit measures eight areas of conservation: two dimensional space, number, substance, continuous quantity, discontinuous quantity, area, and length. For each area the oubject must first recognize that two objects are equivalent along a tested dimension; he must then make a judgment on their equivalency after one object has been changed. The scores of the subjects were compared with the norm, and 
results indicated the children in the experimental group were from one to two years below the norm for the conservation tasks.

Concept development in disadvantaged children has been said to be content-centered rather than form-centered, and reasoning more inductive than deductive (Gordon, 1965). An example of this is the concept dog. A child with an inability to abstract would have difficulty classifying a dog as an animal. He would think of him as something that has four legs and barks (content), and not as part of a large category of Ilving things called animals (form). Gordon (1965) also felt time orientation in middle and upper-class children is more consistent with reality than it is in lower-class children. This most likely results from the lower-class child's inability to use abstract symbols to represent and interpret his feelings, his experiences, and the events of his environment. In summary, all children proceed through a period in whlch they develop certain concepts; concrete object concepts develop earlier than abstract concepts; and observations and experiences have been held to be necessary to concept development. The lower-class child develops his concepts at a later age than the middle-class child, and because of his delayed language development, he experiences much difficulty with the cognitive function of abstracting.

This chąpter may be concluded by stating this investigator has found ilterature supporting the notion that upon school entrence most children from lower-class homes are 
sufficlently delayed in langliage and cognitive development to warrant remediation. Their inability to master the cognitive uses of language impairs their ability to succesd in the academic areas. Most evidence points to the home envircmment of the lower-class child as the largest contributor to his delayed language development. Engelmann (1966) felt all healthy children who have parents interested enough to try teaching concepts will learn the concepts. It appears this teaching Is absent from most lower-class homes because most of the parents in these homes do not have the skills in language to effectively use the time they spend with their children to fec1litate the language and cognitive development that 111 help the children in school.

It was also shown that several authorities consider a knowledge of basic concepts to be essential for success in school. Since the lower-class child is often behind his school age peers in cognitive development, a rapid "catch-up" process is necessary to prevent the children from experiencing academic failure. Identifying the concepts wich the child lacks pould be an essential first step in this process. 
CHAPTER III

METHODS AND PROCEDURES

I. SUBJECTS

Using a random sampling table, one hundred white, lower and midale socioeconomic level children from two elementary schools in Portland School District Number 1 were selected from a subject pool of 150 and were included in this study. Pifty of the children were kindergartrers and fifty. were first graders. At each grade level, twenty-five children comprised each of the two socioeconomic groups.

\section{VARIABLES}

Variables controlled were grade level, auditory acuity, emotional staility, and socioeconomic status. Sex was not a variable and all of the subjects were from a Caucasian population.

Grade Leve 1

The grade levels included were kindergarten and first grade. A chlld who had repeated or was repeating either of these two grades was not included as a potential subject in this study. 
Auditory Acuity

Normal hearing was determined by consulting with the classroom teacher and/or speech clinician. A child who was reported by the teacher to have a suspected hearing loss, difficulty following directions in class, or whose parents had reported a hearing loss was not included as a potential subject. During the time of this investigator's testing, the speech clinician at the two schools was administering a test of auditory discrimination. The results rere noted, and a child displaying an auditory discrimination disorder was not Included as a potential subject.

Emotional Stability

Emotional stability was a subjective judgment made by this examiner. A child whom she felt did not understand the directions, did not respond, did not attend to the task, or othermise was a behavior problem was not included as a potent1al subject in this study.

\section{Socioeconomic Status}

The determination of socioeconomic status was made on the basis of the United States Bureau of the Census Working Paper Number 15, Methodology and Scoring of Socioeconomic Status. The procedure was to assign a number determined by the occupation of the chief income recipient in the child's fam11y. Values ranging from 01 to 40 were considered to be lower socioeconomic status and those from 41 to 83 , middle socioeconomic status. After consultation with the principal, 
children who were on the free lunch progran also were considered to be lower soctoeconomic status.

The occupation of the chlef income recipient in the child's family was obtained by first consulting the school records on each child, which listed the parents' occupation and/or employers. If only the empioyer was listed and not the occupetion, the child and/or a staff member who was famillar with the parents and occupation was consulted. In situations where both parents were employed, the occupation used was that of the chief income recipient.

\section{INSTRUMENTATION}

\section{Instruments}

The Boehm Test of Basic Concepts (BTBC) was designed as a screening and teaching instrument. Information gained from administration of this test may be used as a baseline against which to measure progress after a period of instruction. The test reportedly identifies concepts a child has not yet grasped, but which are essential if he is to understand what others are telling him. This test, therefore, can be used as an effective teaching instrument to enrich the area of concept development. The BNBC has two lettered Forms, $A$ and $B ;$ each form includes two numbered Booklets, 1 and 2. Each test form consists of fifty pictorial items, arranged in approximate order of increasing difficulty and divided evenly between the two booklets. Forms $A$ and $B$ are comparable, 1.e., the sane fifty concepts appear in both forms. In Porms and $B$, 
Booklet 1, the order of presentation of the concepts is identical; the pictures and test stimuli in each form, however, are different. Simllarly, Forms $A$ and $B$, Booklet 2 , contain the same order of presentation, while the pictures and test stimuli differ in each form. Included in the fifty pictorial ttems are twenty-three spatial concepts, four time concepts, eighteen quantity concepts, and five concepts classified as miscellaneous. For the purposes of the present study, Form $A$, Booklets 1 and 2 , were utilized.

The Peabody Picture Vocabulary Test (PPVT) was designed to provide an estimate of a subject's verbal inteligence through measuring his receptive vocabulary. The test consists of numbered plates arranged in approximate order of difficulty, with each plate having a stimulus item to which the child is to point. Testing begins with the stimulus 1 tem corresponding to the child's chronological age, and is discontinued when a basal and celling have been established. The test ylelds a raw score, which can be converted into three types of derived scores: 1) Mental Abillty; 2) Intelligence Quotient; and 3) Percentile Equivalent. There are two forms to the test of approximate equivalence, lettered Forms $A$ and $B$; both forms use the same plates. For the purposes of the present study, Form A of the PPVT was used.

\section{Test Aäministration}

During the first six weeks of the school year 1974-75, the Boehm Test of Basic Concepts and the Peabody picture 
Vocabulary Test were administered to approximately one hundredufifty children in Portland Schood District Number 1. All testing zas executed on an individual basis. The test administration procedure differed at each school because this examiner was asked to conform to a testing procedure which had been previously established by the school and the speech clintcian.

At School $A$, the tests were administered to the kindergartners and first graders within period of a week in conJunction ith a screening program conducted by the school speech clinician. On the first day of testing, Form A, Booklet 1 , of the $B T B C$ was administered to each child. The child was seated at a table across from the examiner with the test booklet placed in pront of him. The examiner read the test stimuil as they appeared in the test manual, and the child pointed to the picture he felt was the correct response to the stimulus item. The examiner recorded an $X$ in the space prov1ded on the record sheet if the child was correct; if the child's answer was incorrect the examiner left the space blank. The administration of Booklet 1 required approximately seven minutes per subject.

During the following week at School A, the kindergarten and first graders were administered Form $A$, Booklet 2, of the BPBC and Form $A$ of the PPVT. For the administration of Porm A, Booklet 2, of the BTBC the child was seated next to the exaniner with the test booklet placed in front of hin. The examiner read the test stimuli as they appeared in the test 
manual, and the child pointed to the picture he felt was the correct response to the stimulus item. Scoring was identical to the procedure utilized in the administration of Form A, Booklet 1. After the administration of Form A, Booklet 2, or the BIBC, the child was administered Form $A$ of the PPVT. The child remained seated next to the examiner with the test booklet in front of him. The examiner read the test stimuli as they appeared in the test manual, and the child pointed to the picture he felt was the correct response to the stimulus 1tem. The child's responses were recorded on the score sheet, and scoring proceeded according to the specifications outlined in the test manual. The administration of the two tests required approximately ten minutes.

At Sehool B, each kindergarten and first grade student was administered the two tests. For each of the tests the child was seated next to the examiner with the test booklet placed in front of him. The examiner read the test stimuli as they appeared in the test manual, and the child pointed to the picture he felt was the correct response to the stimulus item. After the administration of Form A, Booklets 1 and 2, of the BTBC, Form A of the PPVT was administered to each child. Scoring of each test was identical to the procedures followed at School A. The total administration for the two tests required approximately fifteen minutes.

\section{DATA ANALYSIS}

The data were anslyzed in terms of means, standard 
deviations, and "t-tests" to determine if a relationship existed between $\mathrm{BTBC}$ scores and sorioeconomic status.

Four t-tests were performed comparing the difference of the total number of concepts correctly identified by: 1) lowor-class kindergartners and middle-class kindergartners; 2) lower-class first graders and middle-class first graders; 3) all kindergartners and all first graders; and 4) all lowerclass and all middie-class subjects.

An Item analysis of the subjects' responses was made to determine the number of concepts correctly identified in each of three of the four areas assessed by the BTBC (space, time, and quantity). In terms of the number of concepts correctly identified in each category the following groups were compared: 1) all kindergarten and all first graders; 2) ail lower-class kindergartners and all midale-class kindergartners; 3) all lower-class first graders and all middle-class Pirst graders; and 4) all lower-class anō all middle-class subjects. T-tests were performed on each of the three concept areas in each of these four groups of subjects.

Due to the process of varying the testing procedure at each school, t-tests were performed to ascertain the existence of any effect of this variable on the test scores. The following groups were compared: a) the lower-class kindergartners at School $\mathrm{A}$ and the lower-class kfrdergartners at School B; b) the middle-class kindergartners at School $A$ and the middle-class kindergartners at School $\mathrm{B}$; c) the lowerclass first graders at School A and the lower-class tirst 
graders at School B; and d) the middle-class first graders at School $A$ and the middle-class first graders at School B. For the purpose of determining a correlation between the subjects' intelligence scores and their BTBC scores a Pearson Product-Moment correlation was calculated. 
CHAPTER IV

RESULPS AND DISCUSSION

\section{RESULTS}

In order to determine if the variable of different testIng procedures at the two schools had any effect on the BTBC scores, the mean and standard deviation were calculated for each compared group of lower-and middle-class subjects at each school (see Table IV). The mean BTBC scores ranged from 34.40 for the lower-class kindergartners at School A to 33.00 for the lower-class kindergartners at School B; 41.40 for the midale-class kindergartners at School A to 35.45 for the middie-class uindergartners at School B; 37.22 for the lowerclass first graders at School A to 39.31 for the lower-class first graders at School $B$; and 41.20 for the middle-class first graders at School A to 42.06 for the middle-class first graders at School B. To determine if the differences in means were statistically significant, t-tests were performed on the scores of the subjects of each socioeconomic group in each grade between schools. The four values of $t$ appear in Table $\nabla$ and indicate no statistical significance for three of the four conpared groups. The 1.95 value of $t$ for the middleclass kindergartners at the two schools is signiflcant at the 0.05 level of 3igniflcance on a two-talled test. 
TABLE IV

MEAN BTBC SCORES AND STANDARD DEVIATIONS FOR THE NUMBER OF CONCEPTS CORRECTLY

IDENTIPIED FOR EACH GROUP OF

IOWER - AND MIDDLE-CIASS

SUBJECTS AT EACH SCHOOL

\begin{tabular}{|c|c|c|c|c|}
\hline $\begin{array}{l}\text { School and } \\
\text { Group }\end{array}$ & $\begin{array}{l}\text { Number } \\
\text { of }\end{array}$ & $\begin{array}{c}\text { Range } \\
\text { of }\end{array}$ & Mean & S.D. \\
\hline $\begin{array}{ll}\mathbf{A} & 1 . \\
& 2 . \\
& 3 . \\
& 4 .\end{array}$ & $\begin{array}{l}50 \\
50 \\
50 \\
50\end{array}$ & $\begin{array}{l}31-39 \\
37-47 \\
29-45 \\
29-47\end{array}$ & $\begin{array}{l}34.40 \\
41.40 \\
37.22 \\
41.20\end{array}$ & $\begin{array}{l}2.65 \\
3.44 \\
5.11 \\
4.66\end{array}$ \\
\hline $\begin{array}{ll} & 1 \\
& 2 \\
& \\
& 3 \\
& 4\end{array}$ & $\begin{array}{l}50 \\
50 \\
50 \\
50\end{array}$ & $\begin{array}{l}22-44 \\
16-45 \\
30-47 \\
36-47\end{array}$ & $\begin{array}{l}33.00 \\
35.45 \\
39.31 \\
42.06\end{array}$ & $\begin{array}{l}7.81 \\
6.29 \\
5.07 \\
3.08\end{array}$ \\
\hline
\end{tabular}

Groups

1. lower-class kindergartners

2. middle-class kindergartners

3. Lower-class first graders

4. midale-class first graders

TABLE V

VALUES OF T RELATIVE TO BTBC RAW SCORES FOR THE COMPARISONS OF THE SUBTECTS OF

EACH SOCIOECONOMIC GROUP IN

EACH GRADE BETWEEN SCHOOLS

Comparison

Groups

lower-class kindergartners at Schools $A$ and $B$ midale-class kindergartners at Schools $A$ and $B$ lower-class first graders at Schools A and B .37 middle-class first graders at Schools $A$ and $B$

* significant at the 0.05 level 
The results of this study revealed a significant relationship between socioeconomic status and the number of concepts correctly identified by the subjects, as well as between grade level and the number of concepts correctly identified on the BIBC. Tables VI and VII Indicate the mean scores on the BTBC and standard deviations (S.D.) for each of the combined kindergarten and first grade subjects and the two groups of subjects separated into socioeconomic groups.

For the lower-class subjects the means on the BTBC were 33.28 for the kindergartners and 38.56 for the first graders with standard deviations of 7.12 and 5.18 , respectively. The mean scores on the BTBC and standard deviations for the middle-class subjects revealed a mean of 36.64 for the kindergartners and 41.72 for the first graders, with standard dev1attons of 6.30 and 3.83 , respectively.

T-tests were performed on the BTBC scores of the lowerand middle-class kindergartners; lower- and middle-class first graders; all kindergarten and all first grade subjects; and all lower-and middle-class subjects. Table VIII reveals the results of these tests and indicates the levels of signiPlcance on a two-talled test.

The mean age in months for the kindergartners was 65.76 months with a standard deviation of 3.27 , and the mean for the sirst graders was 76.14 months with a standard deviation of 3.88 (see Table IX). To determine if the difference in BTBC scores between the two age levels was significant, a t-test was performed. $t$ of 14.41 indicated the difference 
TABLE VI

MEAN SCORES AND STANDARD DEVIATIONS FOR THE

NUMBER OF CONCEPTS CORRECTLY IDENTIFIED

ON THE BTBC FOR COMBINED KINDERGARTEN

AND FIRST GRADE GROUPS

\begin{tabular}{lcccc}
\hline \hline Grade & $\begin{array}{c}\text { Number } \\
\text { of } \\
\text { Items }\end{array}$ & $\begin{array}{c}\text { Range } \\
\text { of } \\
\text { Scores }\end{array}$ & Mean & S.D. \\
\hline Kindergarten & 50 & $16-47$ & 34.96 & 6.93 \\
First Grade & 50 & $29-47$ & 40.14 & 4.82 \\
\hline
\end{tabular}

TABLE VII

MEAN SCORES AND STANDARD DEVIATIONS FOR

THE NUMBER OF CONCEPTS CORRECTLY

IDENTIPIED ON THE BTBC FOR EACH

SOCIOECONOMIC GROUP

\begin{tabular}{lcccc}
\hline Socioeconomic Group & $\begin{array}{c}\text { Number } \\
\text { of } \\
\text { Items }\end{array}$ & $\begin{array}{c}\text { Range } \\
\text { of } \\
\text { Scores }\end{array}$ & Mean & S.D. \\
\hline lower-class kindergartners & 50 & $22-44$ & 33.28 & 7.12 \\
middle-class kindergartners & 50 & $16-47$ & 36.64 & 6.30 \\
lower-class first graders & 50 & $29-47$ & 38.56 & 5.18 \\
mldale-class ilist graders & 50 & $29-47$ & 41.72 & 3.83
\end{tabular}


TABIE VIII

T-TEST VALUES FOR THE NUMBER OF

CONCEPTS CORPECTLY IDENTIFIED

ON THE BTBC

Soctoeconomic Group

Comparisons

lower-class kindergarten/middle-class

kindergarten

lower-class first grade/midale class

t

df first grade

all kindergarten/all first

all lower-class/all middle class

$1.73 *$

48

$2.40 * * \quad 48$

$4.31 * * * \quad 98$

$2.36 * * \quad 98$

* significant at the .05 level

* significant at the .01 level

** significant at the .005 level

TABLE IX

MEAN AGES IN MONTHS, STANDARD DEVIATIONS

AND VALUE OF $T$ FOR THE SUBJECTS

IN THIS STUDY

\begin{tabular}{lccccc}
\hline \hline Subjects & $\begin{array}{l}\text { Range of } \\
\text { Ages in } \\
\text { Months }\end{array}$ & Mean & S.D. & $t$ & df \\
\hline Kindergartners & $59-71$ & 65.76 & 3.27 & & \\
Pirst Graders & $70-83$ & 76.14 & 3.88 & $14.41 *$ & 98 \\
\hline
\end{tabular}

* significant at the .005 level 
was significant at the .005 level, suggesting the BTBC is sensitive enough to measure the differences between children in the two grade levels included in this study.

An analysis of the conceptual areas of space, time, and quantity on the BTBC was conducted. The test contains twentythree spatial concepts, four time concepts, and elghteen quant1ty concepts. Five concepts classipied as miscellaneous were not analyzed. The mean number of concepts correctly identifled in each category at each grade level together with the standard deviations are indicated in Table $\mathrm{X}$. It is to be noted that the means on the BTBC were 18.24 and 19.98 for spatial concepts, 2.36 and 3.00 for time concepts, and 11.20 and 13.46 for quantity concepts for the kindergartners and first graders, respectively. The small difference in means for the time concepts is probably attributable to the fact that there are only four time concepts on the test.

T-tests were performed on each conceptual category on the BTBC analyzing the number of concepts in each category correctly identified by: 1) all lower-class kindergartners and all midale-class kindergartners; 2) all lower-class first graders and all middle-class first graders; 3) all kindergartners and all first graders; and 4) all lower-class and all middle-class subjects. These results are presented in Table XI.

These igures indicate no significant relationship between socioeconomic status and the number of concepts correct1y identified on the $\mathrm{BTBC}$ in the three conceptual areas at 
TABLE X

MEAN SCORES AND STANDARD DEVIATIONS FOR

EACH CONCEPT AREA ON THE BTBC

BY GRADE LEVEL

\begin{tabular}{llcccc}
\hline \hline Grade & $\begin{array}{l}\text { Concept } \\
\text { Area }\end{array}$ & $\begin{array}{c}\text { Numper } \\
\text { of } \\
\text { Items }\end{array}$ & $\begin{array}{c}\text { Range } \\
\text { of } \\
\text { Scores }\end{array}$ & Mean & S.D. \\
\hline Kindergarten & $\begin{array}{l}\text { Space } \\
\text { Time }\end{array}$ & 23 & $9-23$ & 18.24 & 2.84 \\
& Quantity & 18 & $5-16$ & 11.20 & 2.87 \\
First & Space & 23 & $14-23$ & 19.98 & 2.11 \\
& Time & 4 & $1-4$ & 3.00 & .94 \\
& Quantity & 18 & $8-18$ & 13.46 & 2.09 \\
\hline \hline
\end{tabular}

TABLE XI

MEANS, STANDARD DEVIATIONS, AND VALUES OF $T$ FOR EACH CONCEPT IN FOUR COMPARISON

GROUPS ON THE BTBC

\begin{tabular}{|c|c|c|c|c|}
\hline $\begin{array}{l}\text { Comparison } \\
\text { Group }\end{array}$ & $\begin{array}{l}\text { Concept } \\
\text { Area }\end{array}$ & Means & S.D.S & $\overline{d f}$ \\
\hline 1. & $\begin{array}{l}\text { Space } \\
\text { Time } \\
\text { Quantity }\end{array}$ & $\begin{array}{r}17.80 / 18.68 \\
2.12 / 2.60 \\
10.32 / 11.60\end{array}$ & $\begin{array}{l}2.67 / 2.96 \\
1.30 / .99 \\
2.98 / 2.68\end{array}$ & $\begin{array}{l}1.07 \\
1.45 \\
1.56\end{array}$ \\
\hline 2. & $\begin{array}{l}\text { Space } \\
\text { TIme } \\
\text { Quantity }\end{array}$ & $\begin{array}{r}19.68 / 20.28 \\
2.60 / 3.40 \\
12.80 / 14.12\end{array}$ & $\begin{array}{l}2.41 / 1.74 \\
1.02 / .75 \\
2.02 / 1.96\end{array}$ & $\begin{array}{ll}1.00 & 48 \\
3.07 * * 48 \\
2.27 * \quad 48\end{array}$ \\
\hline 3. & $\begin{array}{l}\text { Space } \\
\text { Time } \\
\text { Quantity }\end{array}$ & $\begin{array}{r}18.24 / 19.98 \\
2.36 / 3.00 \\
11.20 / 13.46\end{array}$ & $\begin{array}{l}2.84 / 2.11 \\
1.17 / .94 \\
2.87 / 2.09\end{array}$ & $\begin{array}{l}3.48 * * * 98 \\
2.91 * * * 98 \\
4.43 * * 98\end{array}$ \\
\hline 4. & $\begin{array}{l}\text { Space } \\
\text { Time } \\
\text { Quantity }\end{array}$ & $\begin{array}{r}18.74 / 19.48 \\
2.36 / 3.00 \\
11.56 / 12.86 \\
\end{array}$ & $\begin{array}{l}2.71 / 2.55 \\
1.22 / 1.01 \\
2.83 / 2.48 \\
\end{array}$ & $\begin{array}{l}1.39 \quad 98 \\
2.78 * * 98 \\
2.45^{*} * 98 \\
\end{array}$ \\
\hline
\end{tabular}

*significant at the .025 level

* significant at the .01 level

***significant at the .005 level

Comparison Groups

1. Iower-class kindergartners and middle-class kindergartners

2. Iower-class first graders and middle-class first graders

3. 811 kindergartners and all first graders

4. all lower-class subjects and all middle-class subjects 
the kindergarten level and in the area of spatial concepts at the first grade level. A significant relationship does appear to exist, however, between socioeconomic status and the number of time and quantity concepts correctly identified at the first grade level. The first graders of the middle socioeconomic level correctly identified more time and quantity concepts than dia their lower-class peers. In adaition, a signiflcant difference exists in all concept areas when one grade level is compared with another and in time and quantity concepts when one socioeconomic group is compared to another. The first grade subjects correctly identified more concepts than the kindergartners, while all of the middle-class subjects correctly identified more time and quantity concepts than all of the lower-class subjects.

To aetermine the relationship between the children's intelligence quotients (I.Q.) as measured by the PPVT and the BTBC scores a Pearson's Product-Moment Correlation was calculated. Results revealed a correlation coefficient of 0.08 , which indicates an extremeiy weak relationship existed between the performences on the PPVT and the BTBC.

\section{DISCUSSION}

Prior to the discussion of the actual null hypotheses tested in this investigation, the variable of the testing procedures will be considered. This investigator feels, generally, the variable of different testing procedures utilized at the two schools ald not effect the subjects' scores on the 
BPBC. A statistical analysis performed on the BTBC scores for the subjects of each socioeconomic level in each grade between Schools $A$ and $B$, revealed this variable did not effect the performances of three of the four compared groups: a) the Iorer-class kindergartners at Schools $A$ and $B$; b) the lowerclass first graders at Schools $A$ and $B$; and $c)$ the middleclass first graders at Schools $A$ and $B$. The variable, however, did appear to effect the scores of the middle-class kindergartners at Schools $A$ and $B$. When the BTBC means of the middle-class kindergarten subjects at the two schools were compared, a $t$ of 1.95 indicated statistical significance at the 0.05 level on a two-talled test. This figure may be reflected in the fact the mean of the middle-class kindergariners at School $A(41.40)$ is above the BTBC mean for all of the middle-class kindergartners $(36.64)$, and closely approximates the mean score for all of the midale-class first graders (41.72). By contrast, the mean for the midale-class kindergartners at School B (35.45) more closely approximates the mean of all of the midale-class kindergartners (36.64). A standard deviation of 3.44 for the middle-class kindergartners at School A Indicates their scores more closely centered around their mean $(41.40)$ than the scores of the middle-class kindergartners at School B (mean, 35.45; standard deviation, 6.29). Since the variable of different testing procedures at the two schools did not influence the BTBC scores of three of the four compared groups, this investigator feels the results of this study were not due to any great extent to the ununiform 
testing procedures.

It was the primary purpose of this study to determine if a statistically significant difference existed between two groups of chlidren in the number of concepts correctly identifled on the BTBC. A secondary purpose was to determine if a positive correlation existed between intelligence as measured by the PPVT and scores obtained on the BTBC. The study tested three null hypotheses. Each will be discussed in this sub-section.

The first hypothesis tested in this investigation was: No statistically significant difference will exist between the total number of concepts correctly identified by: a) the lower-class kindergartners and the middle-class kindergartners; b) the lower-class first graders and the middle-class first graders; c) all lower-class and all middle-class subjects; and d) all kindergarten and all first grade subjects. Relative to this hypothesis, the results of this study show a significant difference between socioeconomic groups in the number of concepts correctly identified on the BTBC. A significant difference was also shown to exist between the number of concepts identified correctly and grade level. The lower socioeconomic group generally identified fewer concepts correctly than the middle socioeconomic group. These results appear to be in agreement with previous research conducted on the disadvantaged child's cognitive and conceptual development. Researchers have stated the disadvantaged child displays a language which inhibits his development of cognitive 
skills such as understanding of concepts (Brottman, 1965; Engelmann, 1966; Deutsch, 1967; Pines, 1967; and Yardley, 1973). The development of an inadequate language system was stated to be the result of several factors: 1) a lack of stimulation materials in the environment; 2) a lack of reinforcement for talking; and 3) a lack of social experiences in the lower-class child's home (Brottman, 1965; Havighurst, 1965; Engelmann, 1966; Deutsch, 1967; and Schiefelbusch, 1967).

At each grade level the middle-class subjects correctly Identified slightly more than three concepts on the BTBC than their lower-class peers. These results would tend to support Moerk's (1973) contention that the language reflected by the lower-class child impairs his ability to abstract. The differences in the number of concepts correctly Identified on the BTBC by each socioeconomic group within a grade level may be a reflection of the difficulty the lower-class subjects experienced in abstracting. Perhaps the pictures on the test d1d not provide a concrete foundation on which to base their responses. Bereiter and Engelmann (1966) have stated that unless the disadvantaged child is provided with a rapid "catchup" process he may fall further and further behind his middleclass peers. The differences in the number of concepts correctly identified on the BTBC between the socioeconomic groups at the Iirst grade level appear to be more significant than at the kindergarten level, and would appear to support Bereiter and Engelmann's (1966) view. When the grade levels were combined, findings revealed a significant relationship existing 
between all lower-class and all middle-class subjects in the number of concepts correctly identified. Again, this may be attributable to the difflculty the lower-class chtldren had in laentifying some of the more abstract concepts of time and quantity.

The findings of this study revealed that the number of concepts correctly identified on the BTBC increased with age when the socioeconomic groups were combined. This investigator suggests that the significant relationship that was found between the number of concepts correctly identified by all kindergartners and all first grade subjects was effected 1.1ttle by the lower-class subjects' scores. It might indicate that both lower- and middle-class flrst graders ldentified more concepts than the lower - and middle-class kindergarten students, respectively, 1.e., both lower- and midale-class students "know" more concepts at the first grade level than at the kindergarten level.: The smaller standard deviation of the first grade subjects (4.82) shows that their scores more closely clustered around the mean (40.14) than did the scores of the kindergarten subjects (standard deviation, 6.93; mean, 34.96).

The significant relationship between the ages of the kindergarten and first grade students appears to indicate that the BTBC is sensitive enough to measure differences in concept development between children in these two grade levels. An examination of the concepts in Appendix A gives the reader an Indication of the difference between grade levels, When 
comparing all kindergartners with all first graders it can be seen that the average difference between the number of concepts correctly identified on the first booklet (concepts 1-25) was 3.56. By contrast, the average aifference between the two grade levels on the second booklet (concepts 26-50) was 8.16. These figures reflect the degree of difficulty in each of the two booklets with Booklet 2 being more difficult. It seems to this researcher that a higher level of abstraction is required to identify concepts in the second booklet, a level of abstraction which may be more developed in a first grader. The significance found in the t-test may, therefore, be related to the difference of 10.38 months between the mean ages of the two grade levels, a "maturation superiority" in age favoring the first graders.

The second hypothesis was: An analysis of the conceptual areas of space, time, and quantity Iy significant difference between the number of concepts correctly identified in each area by: a) the lower- and middleclass kindergartners; b) the lower-and middle-class first graders; c) all lower- and middle-class subjects; and d) all kindergartners and first graders. An analysis of the conceptual areas of space, time and quantity on the BTBC rerealed no significant relationship between socioeconomic status and the number of concepts correctiy identified in each of the three areas at the kindergarten level. Figures 1,2, and 3 illustrate that at each three-month interval the two socioeconomic groups closely approximate each other on time 


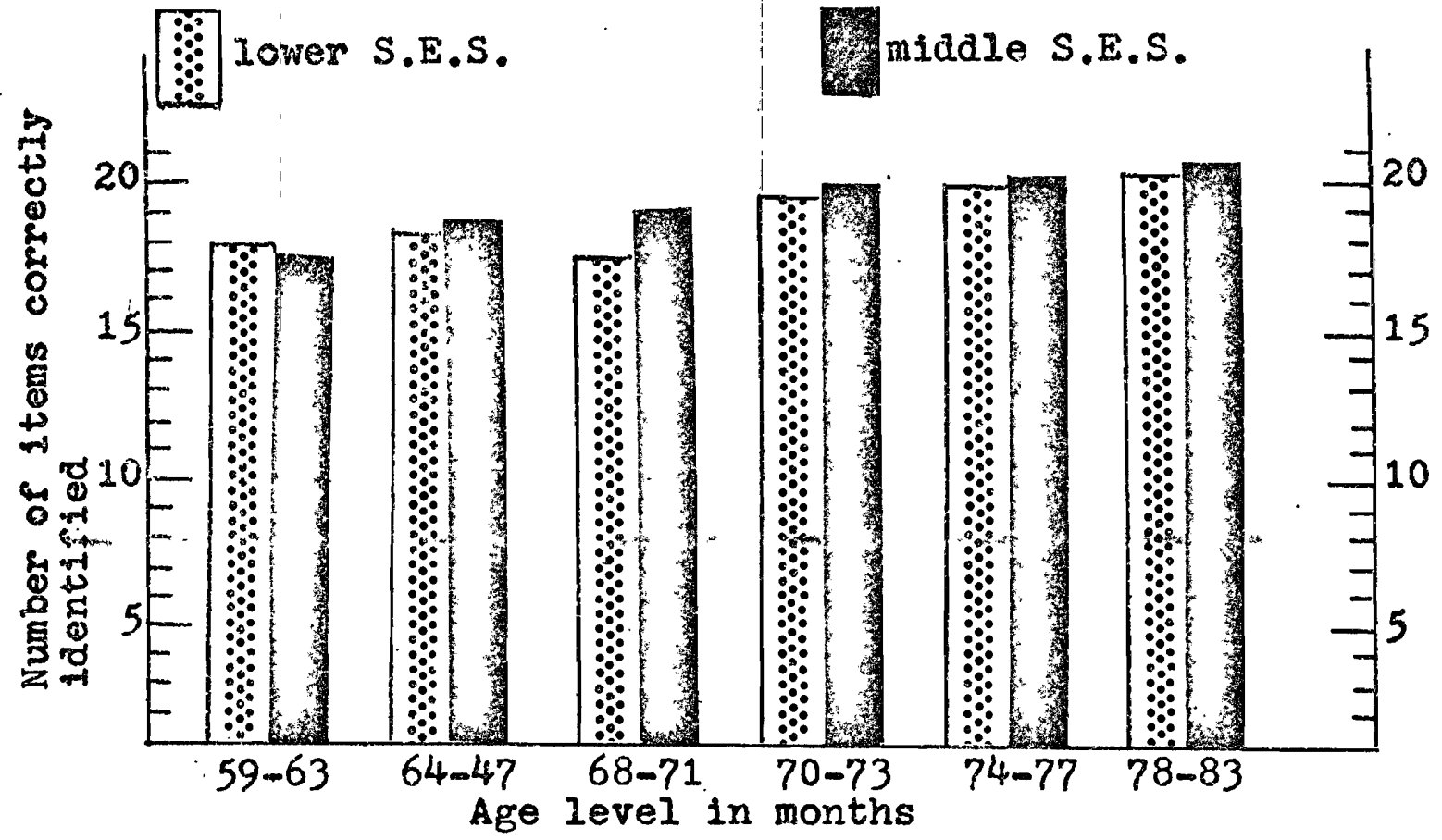

Figure 1. Average number of space concepts correctly identified on the BTBC by kindergartners (59-71 months) and first graders $(70-83$ months $)$.

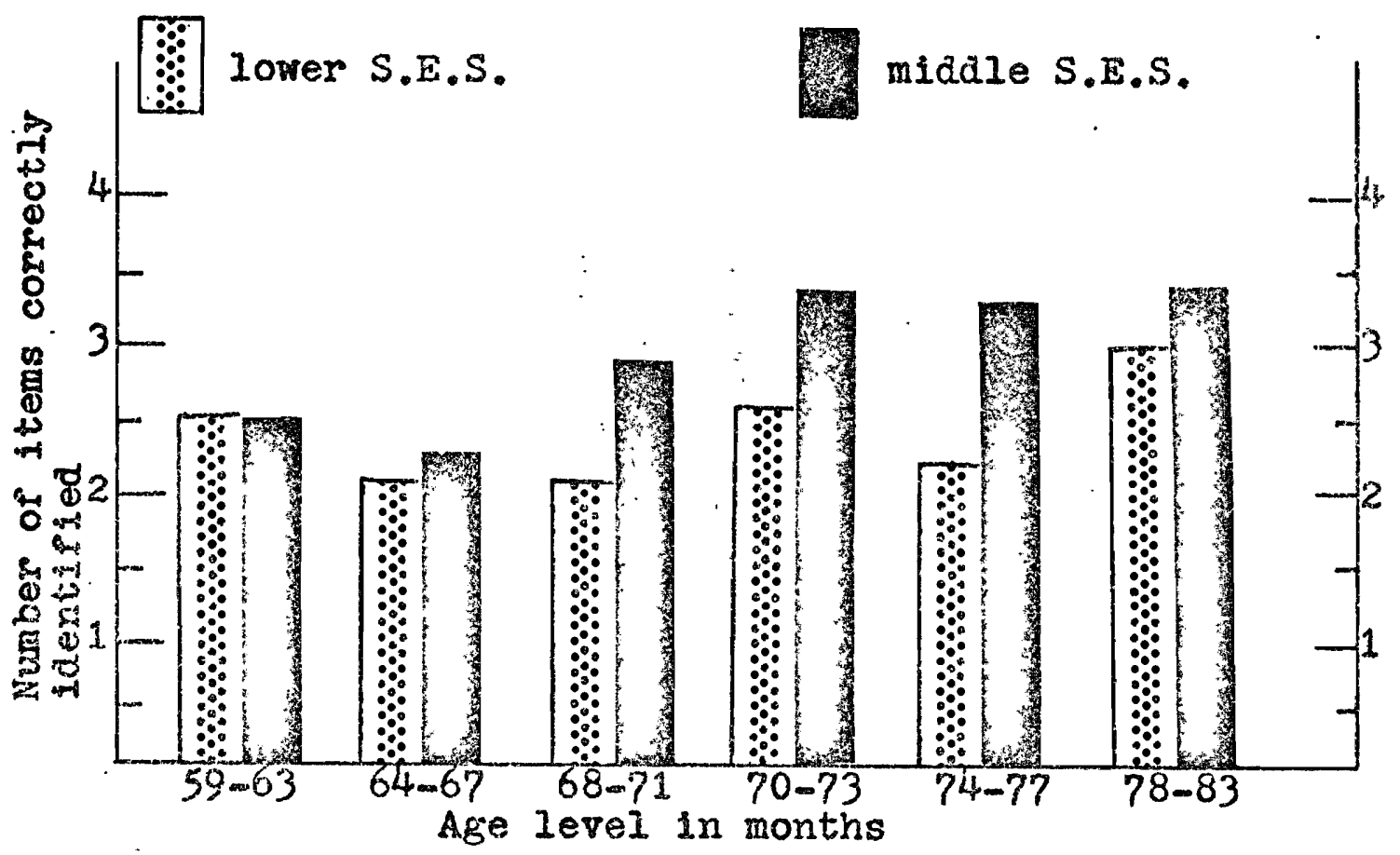

Figure 2. Average number of time concepts correctly identified on the BTBC by kindergartners (59-71 months) and Irst graders $(70-83$ months). 


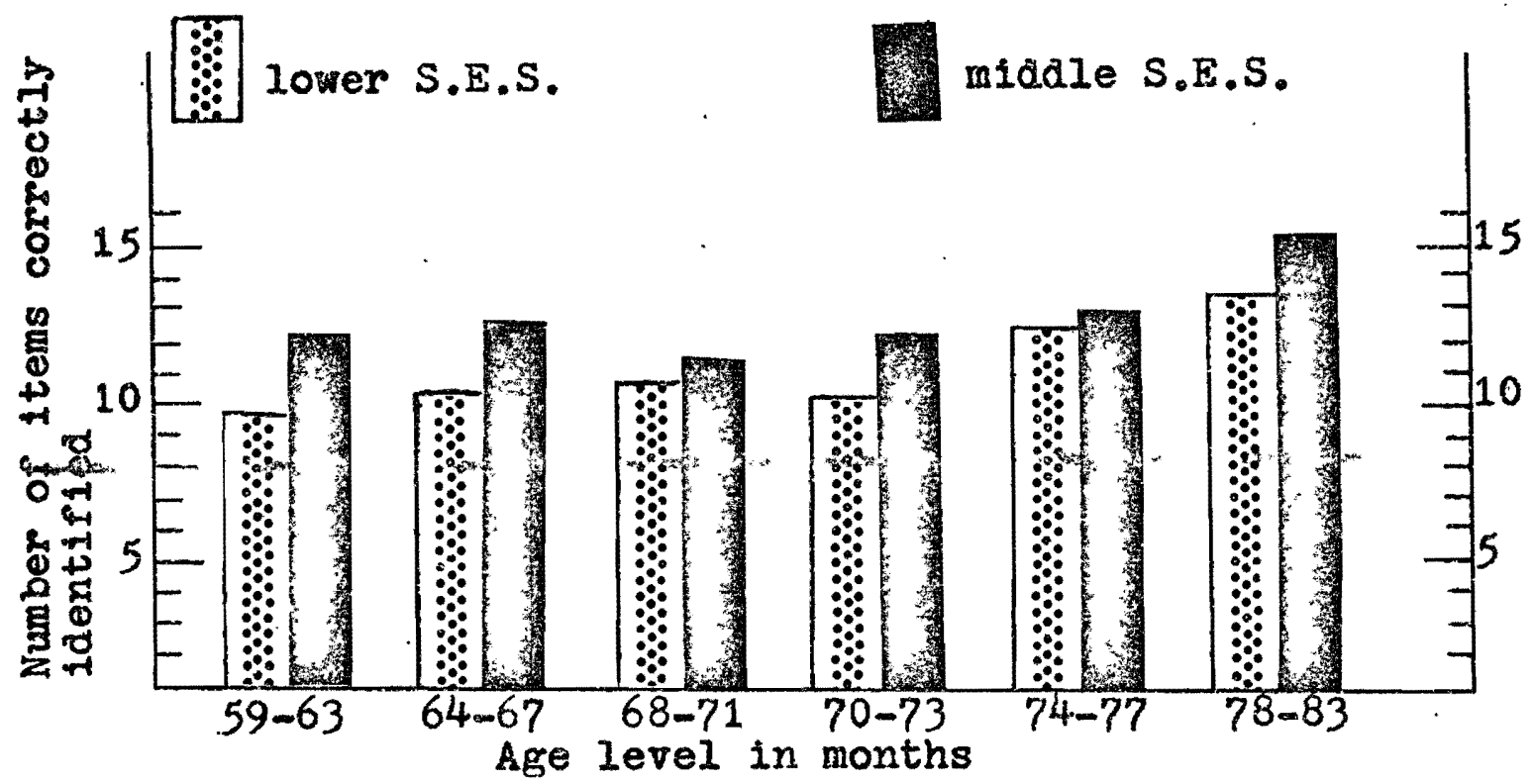

Figure 3. Average number of quantity concepts correctly Identified on the BTBC by kindergartners (59-71 months) and first graders $(70-83$ months $)$.

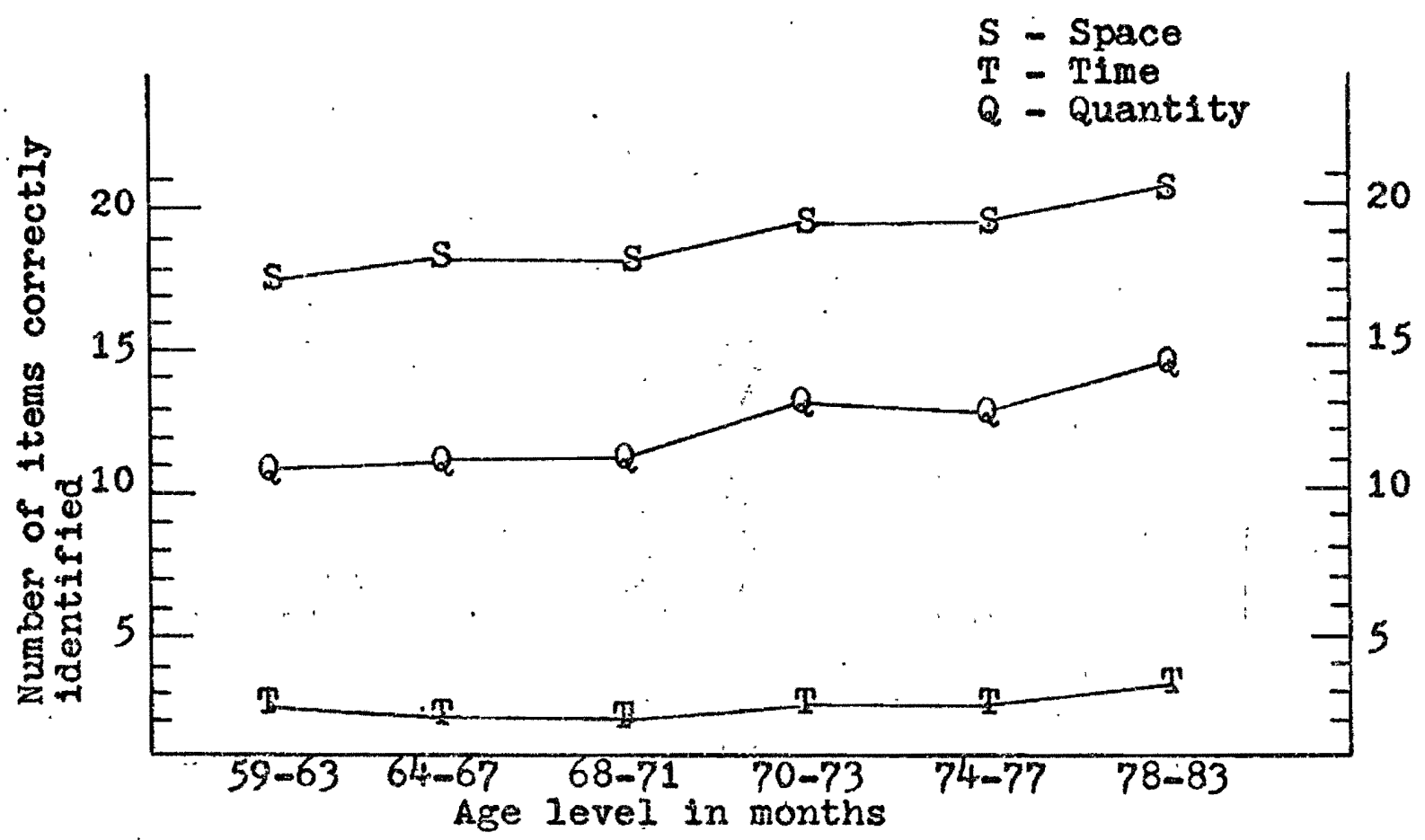

Figure 4. Average number of concepts correctly identifled on the BTBC in each of three categorles by kindergartners ( $59-71$ months) and first graders (70-83 months). 
concepts and at most age intervals on spatial concepts. The intervals of 59 to 63 and 64 to 67 months indicate a wider range between the lower-and middle-class subjects on the quantity concepts; the same relationship may be found at the 68 to 71 month interval for the spatial concepts (see Appendix B). The statistical analysis indicates that these three aifferences were not great enough to result in a statisticalIf significant difference between the lower- and middle-class subjects at the kindergarten level. The number of spatial concepts correctly ldentifled by the first graders did not differ significantly between the lower- and middle-class subfects; nor did they differ when the fifty lower-class subjects were compared to the fifty middle-class subjects. The explanation for this may be that the spatial concepts are the least abstract of the three conceptual areas; presumably, the differences in abstraction levels of the time and quantity concepts separates the two socioeconomic groups more signif1cantly. The average values for each three-month interval for both grade levels may be found in Appendix B.

The development of concepts in each of the three areas measured by the BTBC appeared to be significantly related to grade level. Results of an item analysis comparing the fifty kindergartners with the fifty first graders revealed, generally, that the average number of concepts in each area increased with each three-month interval (see Figure 4). The spatial concepts increased from 17.73 at the youngest kindergarten age interval to 19.66 in the youngest first grade age 
interval; 18.5 to 19.83 in the second age intervals; and 18.27 to 20.41 in the third. Similarly, quantity concepts increased from 10.5 to 13.13 in the youngest intervals; 11.05 to 12.77 In the second age intervals; and from 11.38 to 14.77 in the third (refer to Plgure 4). The time concepts also increased, but the range was not as wide as the other two areas (see Appendix $B$ ). This might be attributable to the small number of time concepts on the entire test. As a child matures he meets new and more varied experiences which help him to develop the ability to identify objects in terms of their common properties. This ability is a component of conceptual development. The increase in the number of concepts correctly identified may be $a$ reflection of the increase in experiences possessed by the maturing child, experiences which also assist the child In his ability to abstract. The ability to abstract is a necessity for a child to respond correctly to this instrument.

This researcher observed an interesting phenomenon in the responses to the items left and right. The tasks were to identify "the bird on the left" and. "the box over the right end of the line." Almost consistently, the chilaren reversed these two, i.e., the response was the "bird on the right" and the "box on the 1eft." Gesell and IIg (1946) have stated that six- and seven-year olds are able to distinguish left and right only in relation to their own bodies. In support of this, it is important to note that the kindergartners in this study identified these two spatial concepts correctly less often than their first grade peers (refer to Appendix A), an 
Indication that first graders are beginning to develop an ability to distinguish left and right other than in relation to their own bodies.

- The third hypothesis tested in thls investigation was: No statistically significant relationship will exist between scores earned by all subjects on the Peabody Picture Vocabulary Test and those scores earned by all subjects on the Boenm Test of Basic Concepts. Relative to this hypothesis, El11s (1972) has stated that intelligence is an important factor in conceptual learning. Children with more intelligence were said to display an ability to solve conceptual tasks consistently faster than less intelligent children. The reason appears to be a result of the more intelligent child's greater ability to construct hypotheses and to use verbal mediating responses, which "... enable humans to respond to Instances in terms of their common properties" (El11s, 1972). A result of this study which would not tend to support this belief is a Pearson's Product-Moment correlation calculated between the subjects' PPVT I.Q. scores and BTBC raw scores, which revealed an insignificant relationship between the two tests with a correlation coefficient of 0.08 . This investigator feels that the lack of a significant relationship may be an indication an intelligent quotient for a hearing vocabulary is not related to the ability to identify concepts. These two tests apparently assess two different skills. Appendix $C$ gires the reader an indication of the lack of $a$ relationship between the two tests by listing the PPVT I.Q. 
65

score and the BTBC raw score for each subject. 


\section{CHAPTER V}

\section{SUMMARY AND IMPLICATIONS}

\section{SUMMARY}

The primary purpose of this investigation was to compare the responses of white, lower-class kindergartners and first graders with white, midale-class kindergartners and first graders on the Boehm Test of Basic Concepts (BTBC) (Boehm, 1969) in order to determine if a statistically significant difference existed between socioeconomic level and the number of concepts correctiy identified on the BTBC. A secondary purpose was to determine if a significant relationship existed between concept development as measured by the BTBC and intelligence from an assessment of receptive rocabulary by using the Peabody Picture Vocabulary Test (PPVT) (Dunn, 1959).

One hundred white, lower and middle socioeconomic level children from two elementary schools in Portland were selected as subjects to be included in this study. Variables controlled were grade level, auditory acuity, emotional stability, and socioeconomic status.

The BNBC consists of pifty pictorial items, arranged in approximate order of difficulty and divided evenly between two booklets. Included in the fifty items are twenty-three spatial concepts, four time concepts, elghteen quantity con- 
cepts, and five concepts classified as miscellaneous. The PPVT was used to provide an estimate of a subject's verbal intelligence through a measurement of his receptive rocabulary. On both tests, the subject was instructed to point to the picture representing the stimulus item.

The results of this study revealed a relationship exists between socioeconomic status and the number of concepts correctly ldentified on the BTBC. This relationship was observed when the lower-class subjects were compared with their middzeclass peers at each grade level, when all kindergartners were compared to all first graders, and in a comparison of the fifty lower-class and fifty middle-class subjects. The subjects of the middle socioeconomic level tended to identify more concepts correctly than the subjects of the lower socloeconomic level, while the first grade subjects, generally, identified. more concepts correctly than the kindergartners. An analysis of the areas of space, time, and quantity revealed that socioeconomic status was related to the number of concepts correct1y Identified when the fifty lower-class subjects were compared to the fifty middle-class subjects. The children of the middle-class identifled more concepts correctly than the lower-class subjects. Grade level also was related to the number of concepts correctly identified in each of the conceptual areas. The first graders tended to identify more concepts correctly in each area than the kindergartners. When the scores of the lower and midale-class subjects at the kindergarten level were compared, there was no relationship 
between socioeconomic status and the number of concepts correctly identified in each of the three areas. No relationship was observed between the scores of the two groups of first graders on the spatial concepts. Socioeconomic level, however, did effect the number of time and quantity concepts correctly identified. The subjects of the middle socioeconomic level, generally, ldentified more time and quantity concepts correctly than the subjects of the lower socioeconomic level.

These results suggest a higher degree of abstraction abilities may be found with increased age and a higher socioeconomic level. The findings also tend to support the views of many researchers in the field of conceptual development who have stated that the language of the disadvantaged child inhibits his ability to abstract.

Results of a Pearson's Product-Moment correlation calculated between the subjects' scores on each of the tests indicated no significant correlation between the children's I.Q. scores and the number of concepts correctly identifled.

\section{IMPLICATIONS}

\section{Clinical}

The results of this study would appear to indicate to classroom teachers and/or speech clinicians that the BTBC could be utillzed to devise language enrichment programs for a whole classroom in a lower socioeconomic setting. This instrument would lend itself to pre- and post-testing to serve 
as a measurement of progress. An important part of this enrichment program should be provisions of expertences and activities which will enable the disadvantaged child to classify and group things. Learning to think of objects in terms of their common properties is an important first step in forming concepts.

The findings of this investigation also may imply that preschools and kindergartens should be provided for children in lower socioeconomic neighborhoods. These preschool experlences will provide the disadvantaged child with an opportunity to develop concepts that he will need to succeed in school. As a supplement to this, indications are that this instrument could be an essential part of a preschool screenIng program. Results could be imparted to the parents, the Implication being that they could facilitate the child's development and understanding of these concepts before he enters school.

\section{Besearch}

This investigator suggests that further research utilizIng the BTBC might be using a larger population, one sufficient enough to establish norms for this area. Different socloeconomic groups and races could be used. Results of the norm standardization could serve as an indication to teachers of the performance of their students in relation to children of the same age in this geographic area.

It is also suggested that a more extensive item analysis 
be done. One analysis could be a notation of the picture to which the child points in response to each stimulus item. This researcher observed that certain trends appeared in the Items the subjects felt were correct. An analysis of this type would provide information relative to the child's stage of the development and understanding of certain concepts. Another analysis, which could be performed, would be a statistical analysis to determine in which order the concepts are developed. This type of analysis would provide general data relative to the years during which the concepts of space, time, and quantity are acquired.

Finaliy, it is felt that a correlation could be made between the BTBC and other tests assessing the knowledge of basic concepts, e.g., Engelmann's (1967) Basic Concept Inventoxy. If a statistically significant correlation exists between the two, the implication would be that the results of each test could be utilized in language enrichment, preschool and/or kindergarten programs. 
SEIECTED BIBLIOGRAPHY

Ames, L.B., The Development of the Sense of Time in the Young child. Journal of Genetic Psychology, 68, 97-125 (1946).

Ames, L.B. and Learned, J., The Development of Verbalized Space in the Young Child. Journal of Genetic Psychology, $72,63-84$ (1948).

Arnone, Vincent C., The Nature of Concepts: A Point of View. Theory Into Practice, 10, 101-108 (1971).

Behrmann, Polly, Is Your Child Ready For School? Journal of Learning Disabilities, 5, 292-294 (1972).

Beller, E., The Concept Readiness and Several Applications. Beading Teacher, 23, 727-737 (1970).

Bereiter, Carl and Engelmann, Siegfried, Teaching Disadvantaged Children in the Preschool. Englewood Cliffs, N.J.: Prentice-Hall, Inc. (1966).

B1ber, Barbara, Educational Needs of Young Deprived Children. Childhood Education, 44, 30-36 (1967).

Blank, Marton and Solomon, Prances, How Snall The Disadvantaged Child Be Taught? Child Development, 40, 47-61 (1969).

Bloom, Benjamin, Davis, Allison and Hess, Robert, (Eds.), Compensatory Education For Cultural Deprivation. New York: Holt, Rinehart and Winston (1965).

Boehm, Ann, The Boehm Test of Basic Concepts. New York: Psychological Corporation (1969).

Boehm, Ann, The Development of Comparative Concepts in Primary School Children. Dissertation Abstracts International, 27-11B, 4109 (1967).

Breshnahan, Jean and Shapiro, Martin, Learning Strategies in Children From Different Socioeconomic Levels. In Hayne Reese (Ed.), Advances in Child Development and Behavior. New York: Academic Press, Inc. (1972).

Brottman, Marvin, Dimensions of the Problem of the Disadvantaged Pupil In Beck and Saxe (Eds.), Teaching the Culturally Disadvantaged Pupil. Springfield, I1l: Charles C. Thomas, Publishers (1965). 
Cooke, Sarah and Cooke, Thomas, Implications of Chlld Development Theories For Preschool Programming. Education, 94, 112-116 (1973).

Deutsch, Cynthia, Learning In The Disadvantaged. In Klausmeir and Harris (Eds.), Analyses of Concept Learning. London: Academic Press, Inc. (1966).

Deutsch, Martin, The Role of Social Class in Language Development and Cognition. In Passow, Goldberg and Tannenbaum (Eds.), Education of the Disadvantaged. New York: HoIt, Binehart and winston, Inc. (1967).

Doyle, Michael, Ianguage Acquisition of Children - Normal and Disadvantaged. Contemporary Education, 43, 161-164 (1972).

Dunn, Iloyd, Peabody Picture Vocabulary Test. Minneapolis: American Guidance Service (1959).

Ellis, Henry, Fundamentals of Human Learning and Cognition. Dubuque, Ia.: W1Iliam C. Brown Co. (1972).

Enmerich, Walter, Disadvantaged Children and Their First School Experiences. ETS-Head Start Longitudinal Study (1973).

Engelmann, Siegfried, Give Your Child A Superior Mind. New York: Simon and schuster (1966).

Engelmann, Siegfried, The Basic Concept Inventory. Chicago: Follett Educational Corporation (1967).

Gesell, Arnold and Ilg, Frances, The Child From Pive to Ten. New York: Harper and Brothers $(1946)$.

Golden, Mark and Birns, Beverly, Social Class, Intelligence and Cognitive Style In Infancy. Child Development, 42, 2114-2116 (1971).

Gordon, Edmund, Characteristics of Socially Disadvantaged Children. Reviem of Educational Research, 35, 377-388 (1965).

Guilford, J.P., The Structure of Intellect. Psychological Bulietin, 53, 267-293 (1956).

Guilford, J.P., Three Faces of Intellect. American Psychologist, $149,469-479$ (1959).

Gullford, J.P., et al. Some Ner Symbolic Factors of Cognition and Convergent Production Educational and Psychological Measurement, 21, 515-541 (1961). 
Gulridge, Beatrice, Happy Journey. Washington, D.C.: National School Pubilc Relations Association (1953).

Havighurst, Robert, The Elementary School and the Disadvantaged Pupil. In Beck and Saxe (Eds.), Teaching The Culturally Disadvantaged Pupil. Springfield, I11: Charles C. Thomas, Publishers (1965).

Houck, Cherry, Biskin, Donald and Fegetz, Jeanette, A Comparison of Urban and Rural Reliability Estimates For The BTBC. Psychology in the Schools, 10, 430-431 (1973).

Ilg, Frances and Ames, Louise, School Readiness. New York: Harper and Row (1972).

Kagan, Jerome, A Developmental Approach to Conceptual Learning. In Klausmeir and Harris (Eds.), Analyses of Concept Iearning. Iondon: Academic Press, Inc. (1966).

Kagan, Jerome, Understanding Children. New York: Harcourt, Brace and Jovanovich, Inc. (1971).

Lee, J. Murray and Lee, Dorris, The Child and His Development. New York: Appleton-Century-Crofts, Inc. (1958).

Locatis, Craig and Smith, Frank A., Performance of Kindergarten Children From Low Income Families on Selected Concept Categories. Paper presented at the Annual California Education Assoc. (1969).

Mann, Marlis, Identifying and Assisting The Development of High Risk Preschool Children. Paper presented at the Annual Meeting of the National Association for Education of Young Children (1972).

Maratsos, Michael, Decrease in the Understanding of the Word "Big" in Preschool Children. Child Development, 44, 747-752 (1973).

McCarthy, Dorthea, The Language Development of the Preschool Child. Minneapolis: The University of Minnesota Press $(1930)$.

Meissner, Judith and Shipman, Virginia, Disadvantaged Children and Their First School Expertences. ETS-Head Start Longitudinal Study (1973).

Mickelson, N.I. and Galloway, C.G., Verbal Concepts of Indian and Non-Indian School Beginners. Journal of Educational Besearch, 67, 55-56 (1973).

Minor, Frances, Cognitive Development: Some Pervasive Issues. Theory Into Practice, 12, 78-87 (1973). 
Moerk, Ernest I., Cognitive Development as Explored by Piaget and Its Impact on Language Development. Paper presented at the UAP-USC Conference on Piagetian Theory and The Helping Professions (1973).

Neal, W.B., The Effects of Environmental Deprivation on Speech and Language Development: Implications for Child Care Workers. Child Care Quarterly, 3, 157-172 (1967).

Palermo, David, More About Less: A Study of Ianguage Comprehension. Journal Verbal Learning and Verbal Behavior, $12,211-221(1973)$.

Phillips, John, The Orlgins of Intellect: Plaget's Theory. San Francisco: W.H. Freeman and Co. (1969).

Pines, Maya, Bevolution in Learning. New York: Harper and Bow $(1967)$.

Beed, Homer and Dick, Dale, The Learning of Generalization of Abstract and Concrete Concepts. Journal Verbal Learning and Verbal Behavior, 7, 486-490 (1968).

Bohles, Frederick, The Middleness Concept in Children. Perceptusl and Motor Skills, 33, 943-948 (1971).

Schiefelbusch, Richard, Language Development and Language Modification. In Haring and Schiefelbusch (Eds.), Methods of Special Education. San Francisco: McGraw-Hill Book Co. $(1967)$.

Smart, Mollie and Smart, Russell, Children, Develooment and Relationships. New York: The Macmilian Co. (1967).

Tennyson, Robert, An Instructional Model for Concept Acquisition (1972).

Thomas, Elizabeth, The Conceptualization Process in Advantaged and Disadvantaged Children. Dissertation Abstracts International, 27-3A, 682-683 (1966).

Tsai, Loh Seng, Chun-Wei and Su Chien, Concept Discovery by School Children: Six Concepts of Middleness. Perceptual and Motor Skilis, 26, 107-114 (1968).

United States Bureau of the Census Working Paper Number 15, Methodoingy and Scoring of Socioeconomic Status, Washington, D.C. (1963).

Wallace, J.G., Concept Growth and The Education of The Child. London: National Foundation for Educational Besearch in England and Wales (1965). 
75

Ward, Muriel, Young Minds Need Something To Grow On. Evanston, I1.: Row, Peterson and Co. (1957).

Was1k, Barbara and Wasik, John, Performance of Culturally Deprided Children on The Concept Assessment Kit-Conservatron. Child Development, 42, 1586-1590 (1972).

Wicker, Allan, Processes Which Mediate Behavior-Environment Congruence. Behavioral Science, 17, 265-277 (1972).

Wolf, Kenneth, Cognitive Development in Disadvantaged Students; Journal of Educational Research, 67, 307-310 (1974).

Yardley, Alice, Young Children Thinking. London: Evans Brotheirs, Ltd. (1973). 


\author{
APPENDIX A \\ NUMBER OF CHIIDREN IDENTIFYING EACH \\ CONCEPT CORRECTLY ON THE BTBC \\ BY SOCIOECONOMIC IEVEI. \\ AND GRADE LEVEL
}

Context Categories:

S - Space (location, direction, orientation, dimension)

$Q$ - Quantity (and number)

T - Time

M - Miscellaneous

Concepts

1. Top

2. Through

3. Away from $s$

4. Next to

5. Inside

6. Some, not many

7. Middle

8. Few

9. Farthest

10. Around

11. Orer

12. Widest

13. Most

14. Between
$\mathbf{S}$

$Q$

Cat
$\mathrm{S}$
$\mathrm{S}$

s

Q

$\mathbf{S}$

Q

S

S

$\mathbf{s}$

Q

S 1.c.k.

23

25

17

22

25

22

23

22

24

25

24

22

21

22 m.c.k.

22

24

18

24

23

24

23

24

23

23

23

24

24

22
25

1.
23
24

22

23

25

25

25

20

25

25

25

22

25

23 m.c. $1^{\text {st }}$

23

25

24

24

25

24

25

17

24

25

25

23

25

23 
Concept

15. Whole

16. Nearest $S$

17. Second

18. Corner

19. Several

Q

20. Behind

S

21. Bow

$\mathbf{S}$

22. Different $M$

23. After

T

24. Almost

Q

25. Ha1f

26. Center

$Q$

27. As many

Q

28. Side

S

29. Beginning $T$

30. Other

M

31. Alike

M

32. Not first or last

33. Never

34. Below

S

35. Matches M

36. Always

T

37. Mediumsized

38. Bight

39. Forward

$\mathrm{S}$

S
Category $\quad \frac{1 .}{16}$

25

16

19

23

19

22

20

16

15

15

21

13

13

13

16

15

14

13

22

19

10

13

13

11
22

25

22

23

23

23

23

22

18

19

17

21

15

19

14

20

16

13

16

23

18

16

17

14

13
21

25

18

19

23

23

24

18

22

20

20

23

19

16

13

21

15

19

21

19

13

19

24

25

18

24

18

16

21

20 
78

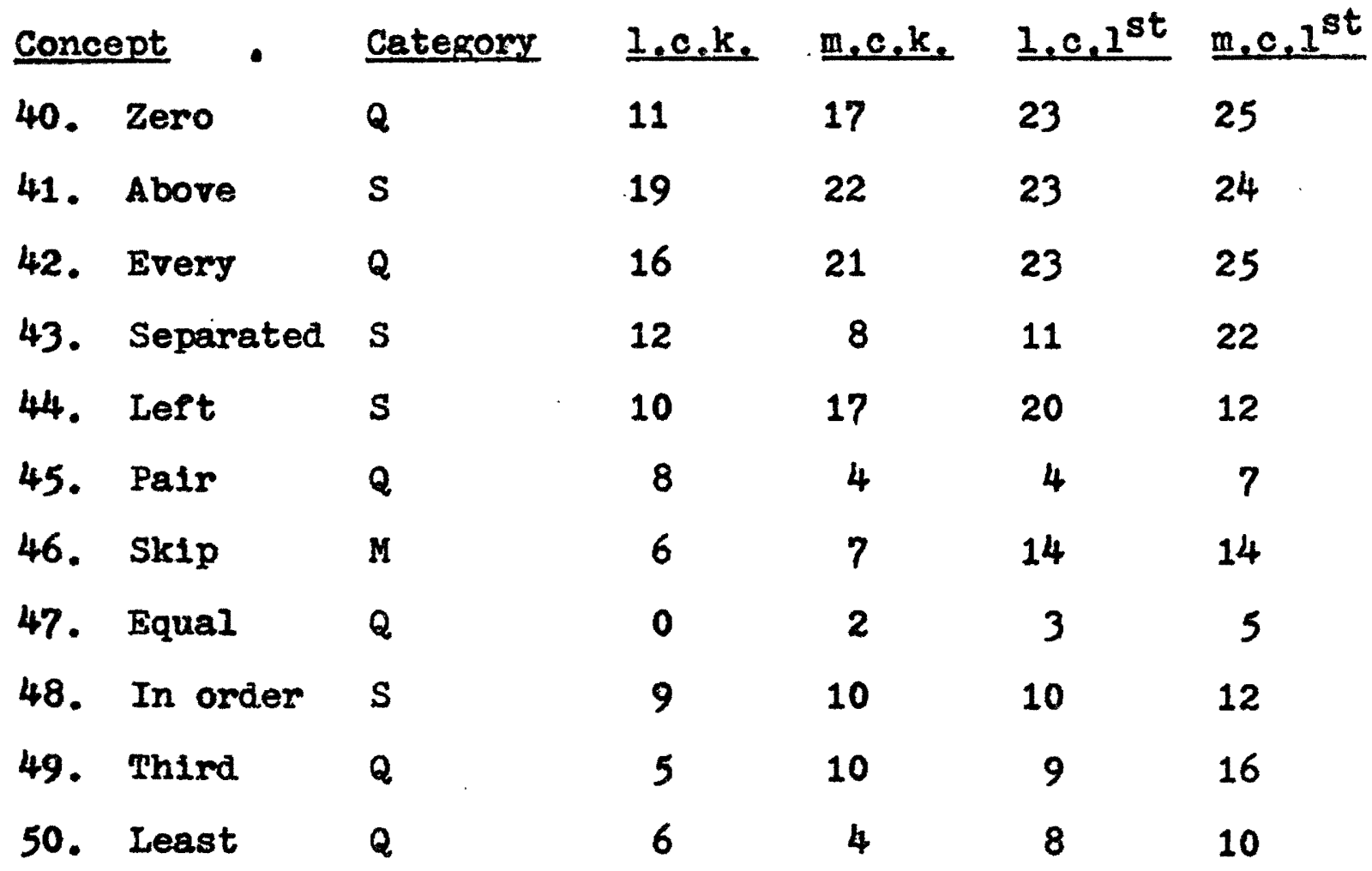




\section{APPENDIX B}

\section{AVERAGE VALUES FOR EACH THREE MONTH INTERVAL BY SOCIOECONOMIC STATUS AND GRADE \\ LEVEL FOR THE BTBC}

$\begin{array}{llrrr}\text { Nonths } & \text { Concepts } & \begin{array}{r}\text { Iower } \\ \text { s.e.s. }\end{array} & \begin{array}{c}\text { middle } \\ \text { s.e.s. }\end{array} & \text { combined } \\ 59 \text { to } 63 & \text { Space } & 17.80 & 17.50 & 17.73 \\ & \text { Time } & 2.50 & 2.50 & 2.50 \\ & \text { Quantity } & 9.80 & 12.25 & 10.50 \\ 64 \text { to } 67 & \text { Space } & 18.14 & 18.72 & 18.50 \\ & \text { Time } & 2.12 & 2.36 & 2.16 \\ & \text { Quantity } & 10.28 & 12.72 & 11.05 \\ 68 \text { to } 71 & \text { Space } & 17.37 & 19.00 & 18.27 \\ & \text { Time } & 2.12 & 2.90 & 2.55 \\ 70 \text { to } 73 & \text { Quantity } & 10.75 & 11.90 & 11.38 \\ & \text { Space } & 19.37 & 20.00 & 19.66 \\ & \text { Time } & 2.62 & 3.42 & 2.77 \\ 74 \text { to } 77 & \text { Quantity } & 10.12 & 12.28 & 13.13 \\ & \text { Space } & 19.55 & 20.11 & 19.83 \\ & \text { Time } & 2.22 & 3.33 & 2.77 \\ 78 \text { to } 83 & \text { Quantity } & 12.55 & 13.00 & 12.77 \\ & \text { Space } & 20.12 & 20.66 & 20.41 \\ & \text { Time } & 3.00 & 3.44 & 3.23 \\ & \text { Quantity } & 13.25 & 15.55 & 14.77\end{array}$




\section{APPENDIX C}

PPVI I.Q. SCORE AND M.A. AND BTBC

RAW SCORE FOR EACH SUBJECT

\begin{tabular}{|c|c|c|c|c|}
\hline Subject & C.A. & PPVTMA & PPVPI.Q. & $\begin{array}{l}\text { BTBC Raw } \\
\text { Score }\end{array}$ \\
\hline 1. & $5-9$ & $5-1$ & 89 & 27 \\
\hline 2. & $5-10$ & $5-1$ & 101 & 33 \\
\hline 3. & $5-6$ & $6-3$ & 103 & 35 \\
\hline 4. & $5-7$ & $4-3$ & 77 & 34 \\
\hline 5. & $5-1$ & $5-1$ & 103 & 31 \\
\hline 6. & $5-10$ & $8-7$ & 127 & 33 \\
\hline 7. & $5-2$ & $9-5$ & 142 & 39 \\
\hline 8. & $5-3$ & $5-1$ & 100 & 33 \\
\hline 9. & $4-11$ & $4-0$ & 85 & 22 \\
\hline 10. & $5-3$ & $5-9$ & 103 & 26 \\
\hline 11. & $6-2$ & $5-11$ & 99 & 44 \\
\hline 12. & $5-1$ & $3-11$ & 83 & 22 \\
\hline 13. & $5-11$ & $5-11$ & 99 & 33 \\
\hline 14. & $5-5$ & $5-9$ & 107 & 40 \\
\hline 15. & $5-10$ & $6-8$ & 107 & 44 \\
\hline 16. & $5-6$ & $6-3$ & 103 & 24 \\
\hline 17. & $5-8$ & $5-7$ & 95 & 32 \\
\hline 18. & $5-4$ & $4-7$ & 92 & 28 \\
\hline 19. & $5-4$ & $6-10$ & 118 & 30 \\
\hline
\end{tabular}




\begin{tabular}{|c|c|c|c|c|}
\hline Subject & $\underline{C_{2} A_{2}}$ & PPVTMA & PPVTI.Q. & $\begin{array}{l}\text { BTBC Raw } \\
\text { Score }\end{array}$ \\
\hline 20. & $5-1$ & $7-1$ & 120 & 44 \\
\hline 21. & $5-9$ & $6-1$ & 103 & 40 \\
\hline 22. & $5-3$ & $5-11$ & 109 & 23 \\
\hline 23. & $5-1$ & $6-8$ & 116 & 44 \\
\hline 24. & $5-10$ & $6-8$ & 107 & 29 \\
\hline 25. & $5-7$ & $9-5$ & 135 & 42 \\
\hline 26. & $5-4$ & $8-1$ & 129 & 37 \\
\hline 27. & $5-10$ & $7-1$ & 111 & 41 \\
\hline 28. & $5-6$ & $6-6$ & 105 & 43 \\
\hline 29. & $5-7$ & $5-2$ & 91 & 39 \\
\hline 30. & $5-8$ & $10-5$ & 145 & 47 \\
\hline 31. & $5-4$ & $5-9$ & 107 & 32 \\
\hline 32. & $5-9$ & $5-11$ & 99 & 39 \\
\hline 33. & $5-7$ & $5-7$ & 95 & 37 \\
\hline 34. & $5-7$ & $7-3$ & 113 & 40 \\
\hline 35. & $5-9$ & $4-11$ & 87 & 35 \\
\hline 36. & $5-9$ & $6-8$ & 107 & 43 \\
\hline 37. & $5-8$ & $6-8$ & 107 & 36 \\
\hline 38. & $5-3$ & $7-3$ & 122 & 27 \\
\hline 39. & $5-5$ & $5-1$ & 100 & 37 \\
\hline 40. & $5-8$ & $5-9$ & 97 & 29 \\
\hline 41. & $5-7$ & $6-6$ & 105 & 40 \\
\hline 42. & $5-10$ & $5-2$ & 81 & 40 \\
\hline 43. & $5-6$ & $4-11$ & 87 & 35 \\
\hline 44. & $5-7$ & $7-1$ & 111 & 45 \\
\hline
\end{tabular}


Subject

45.

46.

47.

48.

49.

50.

51.

52.

53.

54.

55.

56.

57.

58.

59.

60.

61.

62.

63.

64.

65.

66.

67.

68.

69.
C.A.

5-4

5-9

5-0

5-0

5-1

5-8

5-11

6-1

6-5

6-9

5-10

6-7

5-11

6-5

6-3

$6-4$

$6-7$

$6-4$

6-8

6-0

6-3

6-7

5-10

$6-7$

5-10
PPYTMA

6-8

5-9

7-1

5-9

6-3

6-6

5-5

4-11

5-5

6-10

7-3

9-2

$6-3$

7-6

9-2

7-6

7-10

5-11

7-8

$6-10$

6-8

6-6

7-10

8-3

$7-3$
BTBC Raw

PPVTI.Q.

116

31

97

16

120

40

107

32

$114 \quad 38$

$105 \quad 37$

$93 \quad 29$

$87 \quad 39$

$91 \quad 29$

$98 \quad 38$

113

38

122

45

$103 \quad 36$

115

43

$133 \quad 38$

115

43

108

47

99

37

106

45

$109 \quad 45$

$107 \quad 42$

95

30

119

34

112

42

113 
Subject

70.

71.

72.

73.

74.

75.

76.

77.

78.

79.

80.

81.

82.

83.

84.

85.

86.

87.

88.

89.

90.

91.

92.

93.

94.
C.A.

6-2

$6-3$

$6-4$

6-7

6-7

6-11

6-11

6-1

6-11

$6-5$

6-0

6-2

6-0

5-11

5-10

6-9

6-9

6-5

6-7

$6-4$

$6-5$

6-2

6-10

$6-10$

6-2
PPVTMA

5-1

7-3

6-1

7-8

$7-6$

$6-3$

$7-6$

7-1

$7-10$

5-11

$7-10$

$6-3$

7-1

$7-3$

6-10

5-9

6-8

$10-4$

7-6

6-6

11-4

$7-3$

$7-8$

$6-8$

$6-10$
PPVTI.Q.

89

113

101

106

104

93

104

111

108

99

119

103

111

113

109

87

96

143

104

105

143

113

106

96

109
BTBC Raw

Score

34

34

38

41

32

44

47

38

42

44

45

29

43

41

42

41

47

43

40

44

39

41

40

46

43 


\begin{tabular}{lllll} 
& & & \\
Subject & C.A. & PPVTMA & PPVTI.Q. & STBC Raw \\
\hline 95. & $6-2$ & $6-10$ & 109 & 42 \\
96. & $6-0$ & $7-6$ & 115 & 42 \\
97. & $6-3$ & $7-10$ & 119 & 36 \\
98. & $6-9$ & $7-8$ & 106 & 43 \\
99. & $6-0$ & $7-6$ & 115 & 38 \\
100. & $6-7$ & $7-6$ & 115 & 47
\end{tabular}

